\title{
Ecology of Foraminifera
}

in Northeastern

Gulf of Mexico

GEOLOGIGAL SURVEY PROFESSIONAL PAPER 274-G

This report concerns work done

partly on behalf of the U.S. Atomic Energy Commission and is published with the permission of the Commission

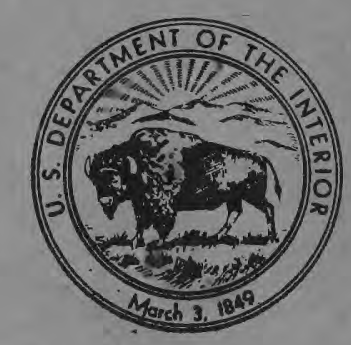


Errata: Prof. Paper 274-G, Ecology of Foraminifera in northeastern Gulf of Mexico.

p. 185, 204 - cjuinqueloculina agglutinata should be Quinqueloculina agglutinans.

p. 186, 204 - Textularia barrettii should be Textulariella barrettii. 


\section{Ecology of Foraminifera}

in Northeastern

Gulf of Mexico

By ORVILLE L. BANDY

A SHORTER CONTRIBUTION TO GENERAL GEOLOGY

GEOLOGICAL SURVEY PROFESSIONAL PAPER 274-G

Frequency distribution of Recent Foraminifera in the coastal waters of western Florida. This report concerns work done partly on behalf of the U.S. Atomic Energy Commission and is published with the permission of the

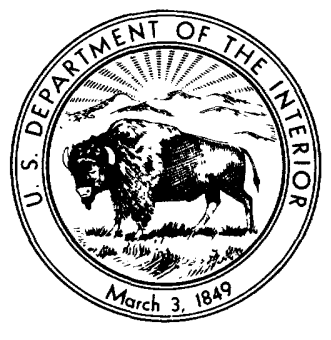
Commission 
UNITED STATES DEPARTMENT OF THE INTERIOR

Fred A. Seaton, Secretary

GEOLOGICAL SURVEY

Thomas B. Nolan, Director

For sale by the Superintendent of Documents, U. S. Government Printing Office Washington 25, D. C. 


\section{CONTENTS}

Abstract
Prtroduction
Methous work of study
Faunal zonation
General features
Brackish habitat
Tampa Bay
Charlotte Harbor, Pine Island Sound, and
$\quad$ San Carlos Bay
Offshore faunal zones.
Fauna 1 (8-40 feet)
Fauna 2 (41-105 feet)
Fauna 3 (106-180 feet)
Fauna 4 (181-250 feet)

\begin{tabular}{|c|c|c|}
\hline ge & & Page \\
\hline 179 & Faunal zonation-Continued & \\
\hline 179 & Offshore faunal zones-Continued & \\
\hline 180 & Fauna 5 (251-600 feet) $\ldots$ & 186 \\
\hline 181 & Planktonic species. & 186 \\
\hline 181 & Environmental analyses..... & 187 \\
\hline 181 & General & 187 \\
\hline 182 & Brackish habitat & 187 \\
\hline 182 & Offishore area & 188 \\
\hline & Paleoecological implications_.......... & 189 \\
\hline 18 & Conclusions .......... & 191 \\
\hline 184 & Faunal reference list & 192 \\
\hline & Systematic paleontology & 198 \\
\hline- & Literature cited & 201 \\
\hline 10 & Index & 203 \\
\hline
\end{tabular}

\section{ILLUSTRATIONS}

[Plates follow index; charts in pocket]

Plates 29-31. Foraminifera of northeastern Gulf of Mexico.

FIGURE 25. Northeastern Gulf of Mexico, showing areas of sampling and biofacies

26. Assemblages and ecologic factors in the river, bay, and shallow-marine habitats

27. Assemblages and ecologic factors in the offshore area

28. Depth and temperature variations during Miocene to Pleistocene time in northern Florida

Chart 1. Foraminiferal distribution in Tampa Bay, Fla.

2. Foraminiferal distribution in Charlotte Harbor, Pine Island Sound, and San Carlos Bay, Fla.

3. Foraminiferal distribution off Mobile, Ala.

4. Foraminiferal distribution off Panama City, Fla.

5. Foraminiferal distribution off Tarpon Springs, Fla.

6. Foraminiferal distribution off St. Petersburg, Fla.

7. Foraminiferal distribution off the Cocohatchee River, Fla.

\section{TABLES}

TABle 1. Median percentages of Foraminifera in Tampa Bay, Charlotte Harbor, Pine Island Sound, and San Carlos Bay ..-

2. Median percentages of significant Foraminifera in the offshore depth zones, based upon concentrate samples.........

3. Foraminifera in selected formations of the Miocene, Pliocene, and Pleistocene of Florida

4. Locations and depths of samples. 


\title{
A Shorter Contribution to General Geology
}

\section{ECOLOGY OF FORAMINIFERA IN NORTHEASTERN GULF OF MEXICO}

\author{
By Orville L. Bandy*
}

\begin{abstract}
Frequency studies of Foraminifera in the northeastern part of the Gulf of Mexico reveal basic uniform patterns of distribution. Samples for the investigation represent the area inshore from the 100-fathom line between Mobile, Ala., and Fort Myers, Fla. Included, also, are Tampa Bay, Charlotte Harbor, Pine Island Sound, San Carlos Bay, and the lower reaches of some rivers.

Brackish waters of bays and harbors are subdivided into shoals and channels, and these in turn are separated into inner, intermediate, and outer bay areas. Faunal assemblages are as follows: river habitat and inner shoals, Ammobaculites and Streblus; inner bays and channels, Elphidium and Streblus; intermediate and outer parts of harbors and bays, Elphidium, Streblus, miliolids, and rare offshore species; and intermediate and outer shoals, abundant Streblus, with few arenaceous species. Salinity variation is the major factor controlling distribution of Foraminifera in the brackish habitat. The greatest weight percentage of Foraminifera and the greatest number of species in the sediment are in the channels and open bay areas. Data from this study together with those from prior workers are used in presenting a classification chart of faunal assemblages for brackish-water habitats.
\end{abstract}

Samples of the offshore area present the following faunal gradation:

\begin{tabular}{|c|c|c|}
\hline $\begin{array}{l}\text { Depth } \\
(\text { feet })\end{array}$ & Prackish areas & Normal-salinity environment \\
\hline $0-40$ & Streblus assemblage $\ldots$ & Archaias angulatus \\
\hline $1-105$ & Hanzawaia strattoni..... & angulatus \\
\hline & Asterigerina carinata $\ldots$ & $\begin{array}{l}\text { Asterigerina carinata } \\
\text { Hanzawaia strattoni }\end{array}$ \\
\hline $6-180$ & $\cdots$ & $\begin{array}{l}\text { Planulina ornata } \\
\text { Hanzawaia strattoni }\end{array}$ \\
\hline & & $\begin{array}{c}\text { concentrica } \\
\text { Cibicides pseudoungerian }\end{array}$ \\
\hline $1-250$ & & $\begin{array}{l}\text { Hanzawaia concentrica } \\
\text { Amphistegina lessonii }\end{array}$ \\
\hline $1-400$ & 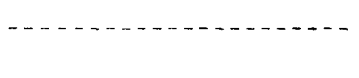 & $\begin{array}{l}\text { Uvigerina assemblage } \\
\text { Amphistegina lessonii }\end{array}$ \\
\hline $01-600$ & - - - - - - - - & $\begin{array}{l}\text { Uvigerina assenblage } \\
\text { Bolivina goёsii }\end{array}$ \\
\hline
\end{tabular}

A composite analysis of the offshore assemblages resulted in the tabulation of median values for the percentages of significant species in each of the faunal zones. The factors limiting the distribution of species in the marine environment are manifold and include temperature, food, nutrients, and other factors. Reduced salinity plays a major role in inhibiting certain species in some nearshore areas; however, turbulence and turbidity are also important. The weight percentage of the Foraminifera in the sediment increases very gradually offshore to the edge of the continental shelf, and then it increases very rapidly beyond this

* Department of Geology, University of Southern Califormia. point. The number of benthonic species increases from less than 20 near the shore to more than 50 on the upper part of the continental slope. Upwelling of colder waters is indicated on the outer part of the continental shelf and may be significant in restricting the distribution patterns of many species.

Different upper limits of the depth ranges of planktonic species demonstrate another method of depth correlation. Globigerinoides rubra (D'Orbigny) appeared in less than 100 feet of water, most of the other species appeared between depths of 100 and 200 feet, and Globorotalia tumida (Brady) appeared at about 400 feet. These data suggest that these species, when alive, float no higher than the minimum depths indicated.

Paleoecological implications are discussed briefly, and an example is given in which the depth-to-temperature relationships are demonstrated for selected formations from the Miocene, Pliocene, and Pleistocene of Florida.

\section{INTRODUCTION}

An investigation was made of the distribution of Foraminifera on the continental shelf and the upper part of the continental slope between Mobile, Ala., and Fort Myers, Fla. (fig. 25). West of central Florida, the outer edge of the continental shelf averages about 210 feet below sea level, and west of northern Florida it averages about 180 feet. The lower part of fauna 4 corresponds approximately with the edge of the shelf off central Florida, and the upper limit of this fauna corresponds roughly with the edge of the shelf off northern Florida. Included in the investigation were Tampa Bay, Charlotte Harbor, Pine Island Sound, San Carlos Bay, and the lower reaches of some of the rivers emptying into these areas. The primary purpose of this study was to discover significant faunal trends and to analyze these in terms of ecologic factors. In this way a better understanding of existing facies may be developed, possibly to serve as a more reliable basis for the interpretation of fossil facies.

The samples were collected from the research vessels MV Pompino and MV Alaska, made available to the U. S. Geological Survey by the U. S. Fish and Wildlife Service. Inshore samples in water shallower than 30 feet were obtained with an underway sampler, whereas those in deeper water were obtained with Pettersson and orangepeel samplers. Positions in inshore areas were obtained by sextant and dead reckoning, and positions in deeper water were obtained by loran (long- 


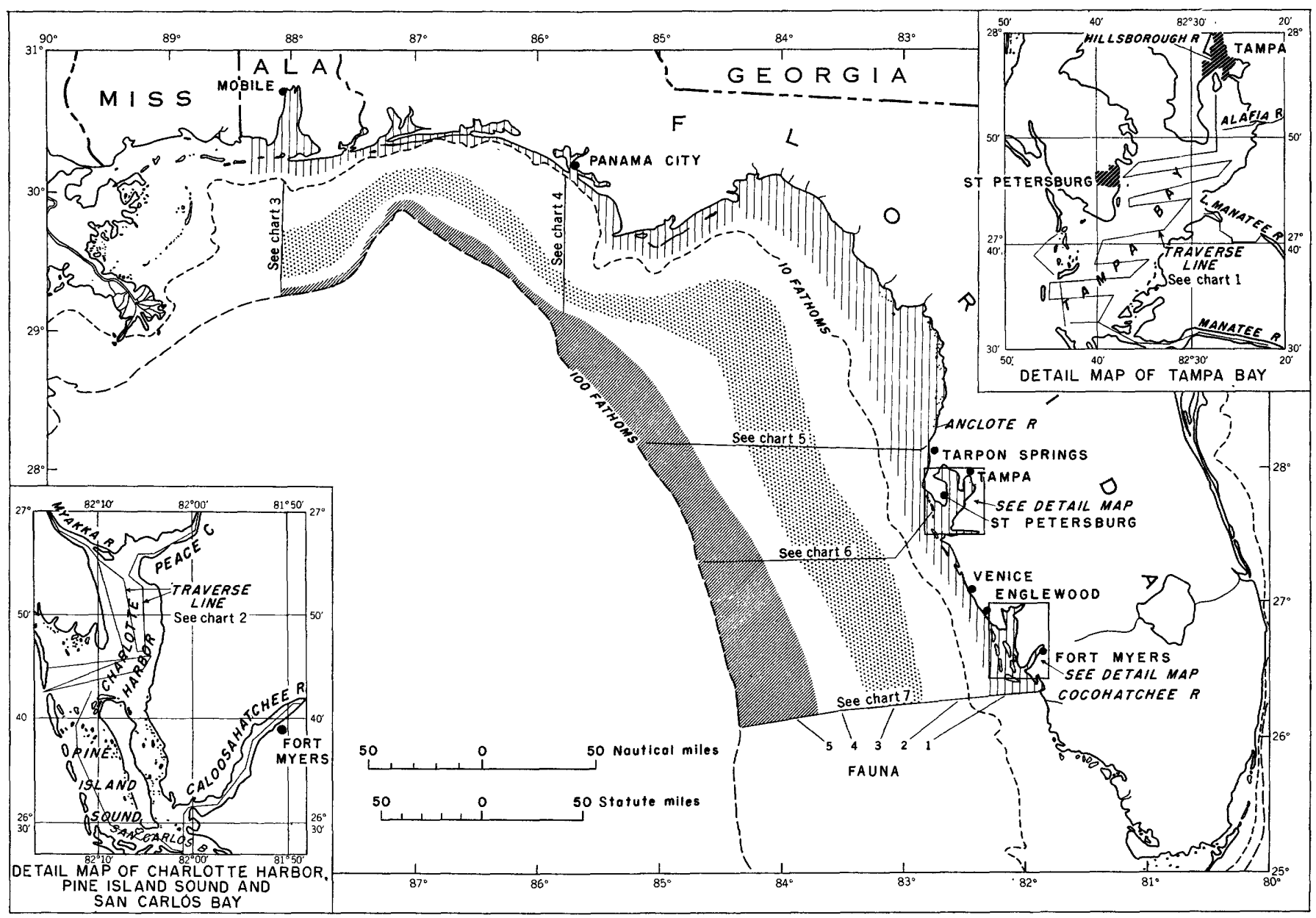

FigURE 25.-Northeastern part of the Gulf of Mexico, showing areas of sampling and biofacies.

range navigation). The samples were taken on behalf of the Division of Raw Materials of the U. S. Atomic Energy Commission chiefly to provide data on the occurrence and distribution of phosphate in bottom sediments of the eastern Gulf of Mexico. This study was directed by H. R. Gould of the U. S. Geological Survey and was financed in part by funds made available by the Atomic Energy Commission. The work on Foraminifera was undertaken by the writer as a part of the study.

Mr. Gould provided much of the data on temperature, salinity, and all of the data on $\mathrm{pH}$ and depth. Additional information on salinity and temperature was obtained from George B. Austin, Department of Oceanography, Agricultural and Mechanical College of Texas, and from J. O. Bell, Acting Chief, Gulf Fishery Investigations, U. S. Fish and Wildlife Service. K. O. Emery, Geology Department, University of Southern California, offered many helpful suggestions in the course of the study. The foraminiferal collections at the U. S. National Museum were consulted in the taxonomic phases of the present investigation, and many courtesies were extended the writer by $A$. $R$.
Loeblich of the Museum and Ruth Todd of the U. S. Geological Survey. The figures of Foraminifera were drawn by Mary E. Taylor. The research for this project was conducted in the micropaleontological laboratory, Allan Hancock Foundation, University of Southern California.

\section{PREVIOUS WORK}

Included in the bibliography are publications of a taxonomic nature on the Foraminifera of the Gulf of Mexico and related areas. The more important publications emphasizing ecology of Foraminifera in the Gulf of Mexico commence with Norton's study of the general trends in Florida and the West Indies regions (1930). He grouped his stations into four bathymetric zones and indicated the types of families common in these. Kornfeld (1931) reported on the Foraminifera in beach samples from 80 stations along the coast of the Gulf of Mexico between the Rio Grande and the Mississippi River delta, and he indicates a prevalence of arenaceous species in embayments. Hedberg (1934) studied the distribution of Foraminifera in Lake Maracaibo and vicinity in Venezuela and gives a considerable 
amount of salinity data in association with the trends there. Parker (1948) has published a significant analysis of the Foraminifera of the continental shelf along the Atlantic coast from Maine to Maryland; however, there are very few abundant species common to both the Atlantic and the coastal waters of western Florida.

Lowman (1949) studied the relative frequency distribution of Foraminifera in the Gulf of Mexico, presenting his results by graphic means and using categories at the generic level for the most part. Israelsky (1949) has demonstrated a significant application of ecology to petroleum geology in his oscillation paper. Phleger and Parker (1951) have presented a wealth of data on the depth ranges of species in the northwestern part of the Gulf of Mexico. Post (1951) has analyzed the shallow-water species of Foraminifera of the south Texas coast. She distinguishes between the assemblages of the closed bays, polyhaline bays, passes, and open gulf, and reports very few arenaceous species in these areas. Parker, Phleger, and Peirson (1953) report four biofacies in San Antonio Bay as follows: opengulf, bay, marsh, and river biofacies. They conclude that the distribution patterns are the result of the relationships between barrier islands, passes, and runoff into the bays. The author (Bandy, 1951, 1954) has completed a study of some shallow-water Foraminifera in a limited area off the Louisiana coast which demonstrates interesting trends among shallow-water species, especially with respect to irregularities on the sea bottom. At the present time, Miss Frances Parker of the Scripps Institution of Oceanography is studying the deeper water environments in the northeastern part of the Gulf of Mexico. The area involved is essentially contiguous with that of this study. With respect to general interest, a most useful and comprehensive bibliography of publications on the Gulf of Mexico was published recently by Geyer (1950).

\section{METHOD OF STUDY}

Analyses of 344 samples were used as a basis for this study. Several additional samples were analyzed but were not used because of their small size and lack of representative faunas. The samples of the two northern profiles were very small and are probably not as representative as those of other profiles. All of the samples were weighed dry, and those which required wasbing were processed on a 240 -mesh screen $(0.064 \mathrm{~mm}$ openings). Next the Foraminifera were concentrated directly from the sediments by the carbon tetrachloride method of separation, and the concentrate was weighed. Considerable error can be introduced into such a weight analysis by the large quantities of small shells and extraneous matter which floats with the formaminiferal oncentrates. This error was eliminated or vastly re- duced by estimating the percentage of Foraminifera in the concentrate and then incorporating this factor into the final weight analyses. Examination of residues following the separations showed fairly clean separations in most cases. The major exception to the adequacy of the separation technique occurred with the Amphistegina lessonii faunas. In some samples many specimens of this species remained with the residues rather than the float; in these an estimate was made of the percentage of Amphistegina in the residues. These values are given separately for the appropriate stations.

Relative frequencies of the foraminiferal species were determined by counting representative fractions of each sample. Counts of from 200 to 500 specimens were usual; however, as many as 1,000 specimens were counted in a few samples and as few as 100 specimens were counted for several samples.

\section{FAUNAL ZONATION GENERAL FEATURES}

As shown in figure 25, there are seven subdivisions of the general area. The first of these is Tampa Bay and the second is Charlotte Harbor together with Pine Island Sound and San Carlos Bay; these consist of brackish shallow-water areas (charts 1,2) which include the associated lower reaches of several streams. Five of the subdivisions are in the offshore area and consist of 5 biofacies paralleling the shore which are based upon 5 lines of samples extending across the continental shelf and down to a depth of about 600 feet (charts $3-7)$. One of the 5 lines of samples is off Mobile, Ala., and is approximately 50 miles long; the remainder are off Florida, and their locations and lengths are Panama City, 65 miles; Tarpon Springs, 140 miles; St. Petersburg, 130 miles; and the Cocohatchee River, 150 miles. The sampled depths off Mobile and Panama City are much more restricted than the others.

All of the data from this analysis are incorporated in the figures of the frequency distribution of Foraminifera (charts 1-7). The first subdivision at the top of each figure, ecologic factors, is designed to show all of the available ecologic data including depth of water, temperature range, salinity range, and the percentage by weight of Foraminifera in the sediment. In addition to the ecologic factors, an algal belt is indicated between depths of 130 and 350 feet which is characterized by an abundance of bryozoans, calcareous algae, and Amphistegina lessonii. Lowman (1949) reported the presence of this algal belt in his investigation of the Gulf of Mexico. Amphistegina lessonii was restricted to the outer part of the algal belt, ranging in depth from about 170 to 350 feet. Abundant bryozoans were found between depths of 130 and 350 feet. According to Howard Gould (oral communication) the calcareous 
algae were found in a nonliving state at the time of collection, and they appear to represent reef structures that developed during times of lowered sea level in the Pleistocene. Archaias assemblages within the algal limestone corroborate this suggestion. Further, Amphistegina limestone was found at greater depths than the Archaias limestone, showing how the faunal zones were displaced downslope during times of reduced sea level. Many of the specimens of Amphistegina are discolored, but many are also very fresh in appearance and are considered to inhabit the reef structures at the present time.

The second subdivision of the frequency figures, the composite frequency graph, is designed to show the gross relations between the arenaceous, porcelaneous, and hyaline groups of benthonic Foraminifera. Planktonic species are plotted as a separate category in this graph. In the third subheading, frequency distribution of species, the benthonic species are segregated into depth suites and plotted against 100 percent of the total benthonic population. Arenaceous species are plotted together, separate from the other species. All values of less than 1 percent are indicated as 1 percent; all other values are to the nearest 1 percent.

A summary of the distribution patterns of Foraminifera is presented in tables 1 and 2 , wherein median values are given for the frequencies of species in the habitat subdivisions. Figures for each of these subdivisions total mostly somewhat less than 100 percent except in the river habitat (fig. 25) and in a branch of the inner channel, where the totals are 116 and 107 percent respectively. This incongruity stems from the fact that there are too few samples, and Streblus is very abundant in the mouths of the rivers and is replaced in large part in upstream areas by Ammobaculites. Additional samples would have resulted in better median values for this habitat. Figures 26 and 27 represent abbreviated classifications of the faunal assemblages and the available ecologic data.

A group of 17 samples, collected in the offshore area between Tarpon Springs and St. Petersburg, was preserved in alcohol. This number is in addition to the 344 samples used in compiling the frequency graphs. As determined by the rose bengale stain method (Walton, 1952), less than 1 percent of the Foraminifera were live specimens. Three of the samples contained the Planulina assemblage and represented depths ranging from 156 to 258 feet, the normal depth range indicated for this assemblage in the frequency profiles (charts $5-7$ ). The remaining 14 samples contained the normal Archaias assemblage and represented depths ranging from 18 to 60 feet, again well within the depth zone indicated in the profiles, especially off Tarpon Springs. Estimates of the relative frequency of stained (live) specimens accorded with frequencies of the dead assemblages.

Many replaced (phosphatized?) or discolored Foraminifera occurred in the preserved samples, and all such species were represented by other specimens that were living. More complete data concerning this phase of the investigation will be included in another Geological Survey report, on sedimentation, by H. R. Gould and R. H. Stewart.

\section{BRACKISH HABITAT}

In the brackish inland waters, the salinity ranged from less than 0.04 to 28.14 parts per thousand. The range of $\mathrm{pH}$ was $6.30-8.22$, and the temperature range was $13.9^{\circ}-19.8^{\circ}$ C. Percentages by weight of Foraminifera in the sediments were mostly less than $1 / 2$ of 1 percent, and the number of species increased generally from 5 or less in the shallow inner areas to 20 or more in the channels opening into the gulf (charts 1,2). Arenaceous Foraminifera were dominant in the lower reaches of the rivers, whereas the porcelaneous species were of greatest importance in open bays and especially in the channels. Hyaline species were abundant throughout most of the bay areas.

\section{TAMPA BAY}

In chart 1 it is apparent that there are two main subdivisions of Tampa Bay regarding bottom configuration. These are shoals and channels, each of which is further subdivided into bay-head, intermediate, and bay-mouth areas. In the shallower waters of the bayhead environment there is an abundance of Ammobaculites salsus, Streblus tepidus, and little else; in the intermediate and bay-mouth shoals occur Streblus, species of Elphidium, a few other genera, but no specimens of Ammobaculites. The channels of the inner area exhibit an abundance of Streblus tepidus and S. sobrinus; the intermediate channels exhibit high frequencies of Quinqueloculina akneriana, Q. jugosa, Triloculina trigonula, Streblus tepidus, and Textularia secasensis; and the bay-mouth channels show an increase in the frequency of Streblus tepidus, the appearance of species of Elphidium which were mostly absent in the intermediate channels, and a more equal emphasis of the miliolids and other species. Prominent trends and distinctions of faunal subdivisions include diversification of species toward the bay mouth in both shoals and channels, and a fairly distinct separation of the shoal and channel faunas. That is, the inner shoals exhibit Ammobaculites, and the inner channels have an abundance of Streblus sobrinus and S. tepidus; porcelaneous species are rare on the intermediate and outer shoals, whereas the channels associated with these areas have abnormally high concentrations of these species. Elphidium gunteri appeared in minor numbers 
in shoal areas near the mouths of rivers and around the edges of some of the channels. No Foraminifera were found on the shoal represented by samples 503-506 where diatoms formed the dominant part of the sediment; however, Streblus sobrinus and Elphidium gunteri were especially large and well developed in the edges of this shoal.

Measurements of temperature, $\mathrm{pH}$, and salinity were made in December, and the indicated ranges are representative of the variation found in the bay at that time of year. The temperature range of $15.8^{\circ}-18.1^{\circ} \mathrm{C}$. is probably the annual minimum. Streams entering Tampa Bay exhibited a temperature range of $10.6^{\circ}-$ $19.4^{\circ} \mathrm{C}$. In the shallow waters of the bay, temperature is probably not significant in so far as the faunal subdivisions are concerned; however, it is probably significant in distinguishing between these faunas and those of the bays in colder regions. A pH minimum of 6.9 was reported at one place in the Little Manatee River; excepting for this, the $\mathrm{pH}$ of the rivers ranged between 7.07 and 8.00 , thus only slightly lower than the range of 7.20-8.12 for the bay. Observed variations in $\mathrm{pH}$ may be adequate to affect faunas in parts of the bay, but it is unlikely that this factor is important in distinguishing between the general faunal subdivisions. Perhaps reduced $\mathrm{pH}$ is contributory to the decline of hyaline species and the disappearance of porcelaneous species in the river habitat. Salinity measurements ranged from 6.6 to 24.2 parts per thousand within the bay, whereas those of the rivers were mostly less than 0.4 parts per thousand. According to Gould (oral communication) there is a flow of less dense fresh water over the denser saline waters of the bay. This would tend to modify the faunal environment of shoal areas in the path of such currents, possibly explaining the absence of Foraminifera on some shoals such as the one mentioned above (samples 503-506). The percentage of Foraminifera in the sediment is much greater in the channels and open bay areas than on the shoals (chart 1), and this may well be explained by the same salinity characteristics, the more saline deeper waters promoting a larger and more diversified marine population.

CHARLO'T'TE HARBOR, PINE ISLAND SOUND, AND SAN CARIOS BAY

Chart 2 illustrates the ecology of the Foraminifera of Charlotte Harbor, Pine Island Sound, and San Carlos Bay. Faunal studies suggest three main subdivisions of these areas: river habitat, inner harbor and inner bay areas, and outer harbor or bay areas. In these waters, unlike Tampa Bay, the shoals and channels are poorly defined and there is little or no faunal differentiation between them (see table 1).

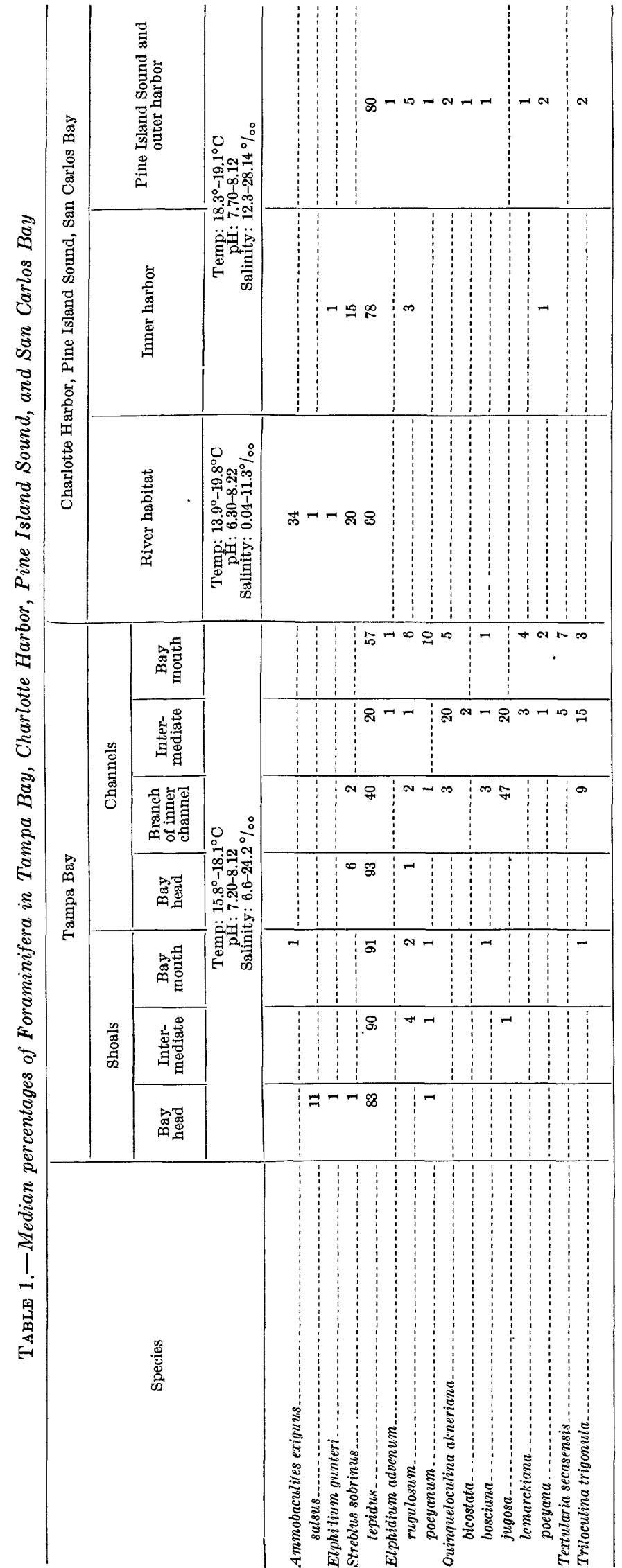


The river habitat displays a predominance of $A m m o-$ baculites exiguus in the upstream areas, whereas in the downstream areas there is an important influx of Streblus sobrinus and S. tepidus. The inner harbor and inner bay areas are characterized by the continued prevalence of Streblus sobrinus and S. tepidus, the absence of Ammobaculites, and the appearance of Elphidium rugulosum, E. advenum, and an occasional Quinqueloculina (table 1). The outer harbor and outer bay areas show considerable faunal diversity with the appearance of many miliolids and the absence of Streblus sobrinus.

Temperature, $\mathrm{pH}$, and salinity measurements (chart 2) were made during the month of December. Temperatures fell as low as $13.0^{\circ} \mathrm{C}$. in the rivers, whereas the bay temperatures were between $18.3^{\circ}$ and $19.1^{\circ} \mathrm{C}$. Fluctuations of temperature are characteristic of these shallow waters, and, therefore, change of temperature, rather than the values, may be the control. The effect of temperature, however, is likely of minor importance in determining faunal differences within the area. Values of $\mathrm{pH}$ are mostly above 7 ; however, there is a trend toward lower, more acid conditions in the rivers. This correlates with the decrease of porcelaneous and hyaline Foraminifera in these areas. Variation in salinity is considered the most significant controlling factor in the harbors and bays. The salinity is less than 0.04 parts per thousand in the rivers, about 11 parts per thousand near the mouths of rivers, and more than 28 parts per thousand in the harbors and bays. Foraminifera are known to be typically marine animals. Therefore, the observed salinity gradient is considered as the probable controlling factor. Maximum tolerance to variations in salinity is observed in Ammobaculites, somewhat less is attributed to Streblus, less yet to species of Elphidium, and the. least tolerance is observed in most other genera of hyaline and porcelaneous species.

Percentages of Foraminifera in the sediments of Charlotte Harbor, Pine Island Sound, and San Carlos Bay were confined mostly to less than $1 / 2$ of 1 percent, about the same as that in the adjacent offshore area. This suggests a relatively low productivity of Foraminifera with respect to sedimentation rates.

\section{OFFSHORE FAUNAL ZONES}

The detailed frequency data for all of the species are presented in charts $3-7$. The progressive changes in the faunal character with increase in distance from land and depth of water made it possible to segregate the species into 5 arbitrary faunal groups between the depths of 8 and 600 feet. The arenaceous species are listed separately and in sequence according to increasing depth. There is a patent intergradation of faunal groups, and many of the rarer species occur in different faunas in the different profiles. Generally these rarer species are more widely distributed, and they are, therefore, less diagnostic of restricted depth zones. The more abundant and restricted species were analyzed statistically in an effort to determine dependable depth indices, and these data, representing a composite generalization drawn from the five offshore profiles, are presented in table 2 . The figures in this table are median percentages of occurrence of significant Foraminifera for the depth ranges given.

The samples in the offshore profiles demonstrate many interesting general trends. In the 3 southern profiles the number of species generally increases from

TABLE 2.-Median percentages of significant Formaminifera in the offshore depth zones, based upon concentrate samples

\begin{tabular}{|c|c|c|c|c|c|c|}
\hline \multirow{2}{*}{ Species } & \multicolumn{6}{|c|}{ Depth zones (feet) } \\
\hline & $8-40$ & $41-105$ & $106-180$ & $181-250$ & $25-400$ & $401-600$ \\
\hline \multicolumn{7}{|c|}{ Fauna 1} \\
\hline Elphidium gunteri. & 5 & 1 & & & & .... \\
\hline poeyanum & 19 & 3 & 3 & 1 & & $\ldots$ \\
\hline Streblus tepidus & 48 & 1 & 1 & $-\ldots$ & & \\
\hline
\end{tabular}

\begin{tabular}{|c|c|c|c|c|c|c|}
\hline \multicolumn{7}{|c|}{ Fauna 2} \\
\hline Archaias angulatus........... & 143 & 11 & 1 & $\ldots$ & 貝 & \\
\hline Asterigerina carinata. & 5 & 20 & 1 & 1 & & \\
\hline Discorbis floridanus. & 2 & 8 & 1 & 1 & & \\
\hline concinnus & 1 & 13 & 2 & 1 & & \\
\hline $\begin{array}{l}\text { Hanzawaia concentrica. } \\
\text { strattoni }\end{array}$ & 1 & 18 & 18 & 13 & 5 & \\
\hline $\begin{array}{l}\text { Textularia candeiana } \\
\text { mayori }\end{array}$ & & 4 & 5 & 3 & & \\
\hline
\end{tabular}

\begin{tabular}{|c|c|c|c|c|c|c|}
\hline \multicolumn{7}{|c|}{ Fauna 3} \\
\hline Bigenerina irregublaris. & 1 & 4 & 10 & 10 & 4 & 1 \\
\hline Planulina ornata & $\ldots$ & 2 & 16 & 16 & 5 & $\cdots$ \\
\hline
\end{tabular}

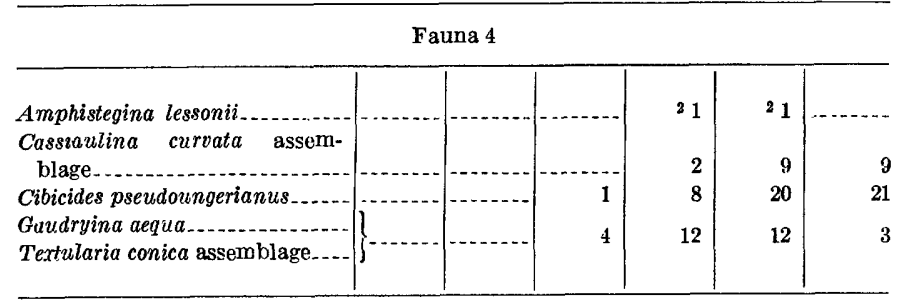

Fauna 5

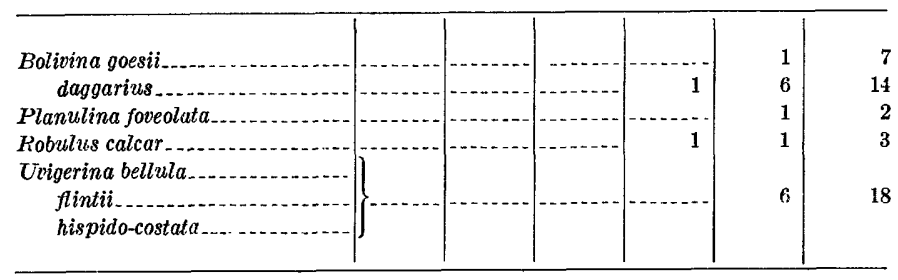

1 Representative for areas of normal salinity only; 1 percent otherwise.

2 Represents ocourrence in concentrate; it would range from 10 to 70 percent of unconcentrated fauna. 
about 20 in the nearshore area to more than 50 at the outer ends of the deeper profiles. The weight percentage of the Foraminifera in the sediment fluctuates from less than 1 percent near the shore to about 2 percent on the outer part of the continental shelf and then increases rapidly on the continental slope, an increase which coincides with the progressive increase in planktonic tests in the sediment. Two exceptions to this generalization include an increase in the percentage of Foraminifera due to the abundance of porcelaneous species in less than 100 feet of water and sporadic percentage increases near the edge of the continental shelf because of the abundance of Amphistegina lessonii. Percentages of Foraminifera in the sediments of the northern profiles are mostly less than 1 percent, a smaller value that is caused by correspondingly larger contributions of sand and silt. In the southern profiles, porcelaneous species are of very high frequency in less than 100 feet of water, whereas they are minor constituents in the shallow waters of the northern profiles. Arenaceous species show a depth zonation like that of the other types of Foraminifera. In the southern profiles these comprised less than 10 percent of the fauna in shallow water, whereas they amounted to more than 20 percent of the fauna toward the edge of the continental shelf. The arenaceous types were quite abundant throughout the northern profiles.

One good example of a bottom prominence was noted in the Panama City profile (chart 4) where the offshore declivity of the bottom is interrupted at about 118 feet and shoals to about 104 feet (stations 354-359) before continuing downward again. This configuration is reflected in the faunal trends by a decrease in the percentage of arenaceous species and an increase in the percentage of porcelaneous species on the prominence. Quinqueloculina lamarckiana exhibits the greatest increase in frequency at this locality and is in large part responsible for the increase in the porcelaneous category.

\section{FAUNA 1 (8-40 FEET)}

The dominant species of fauna 1 are Streblus tepidus, Elphidium gunteri, and E. poeyanum. Species which are important, but less consistently present, include Elphidium advenum, E. mexicanum, Quinqueloculina akneriana, Q. jugosa, Streblus sobrinus, and Textularia secasensis.

Under some conditions Archaias, and to a lesser extent Asterigerina, occur in abundance in depths of 8105 feet (chart 5) whereas under other conditions they are restricted to a depth range of about 41-105 feet (charts 6, 7). Where Archaias is present in the shallower waters, Streblus is absent or very rare. The explanation of this situation may be that the Streblus fauna is developed in brackish waters, whereas Archaias is restricted to inshore waters of normal salinity. Other species listed for fauna 1 are not as variable in their occurrence and are usually found at the normal depths for this fauna.

\section{FAUNA 2 (41-105 FEET)}

Dominant species of fauna 2 include Asterigerina carinata and Archaias angulatus in the southern profiles, whereas the following species were found in the indicated depth ranges in all areas: Discorbis floridanus, $D$. concinnus, Hanzawaia strattoni, Textularia candeiana, and T. mayori. The last two species occur in low frequencies together, so they were combined for simplicity in computing median percentages of occurrence. Not shown in table 2 are other species of importance such as Peneroplis proteus, Quingueloculina agglutinata, $Q$. dutemplei and Q. horrida. As shown in charts 3-7, many other species occur in this fauna, but generally they are not as specific for the specified depth range. Hanzawaia strattoni is very abundant between depths of 41 and 105 feet; however, young specimens of this species are difficult to separate from young specimens of the deeper occurring $H$. concentrica, so the 2 were combined in the frequency counts. $H$. strattoni is predominant in the upper half of the depth range whereas $H$. concentrica is the more abundantly represented member in the lower half of the range. Hanzawaia strattoni is found in fauna 1, but it is rare. This agrees with the findings of Parker, Phleger, and Pierson (1953) that it is a rare species in very shallow waters and beach sands.

In table 2 it may be noted that fauna 2 identifies the 41- to 105-foot depth in 3 ways: certain species range mostly from these depths into shallower depths, as Asterigerina carinata and Archaias angulatus; other species range mostly from these depths downward as shown by Hanzawaia strattoni, Textularia candeiana, and T. mayori; and other species that are rare or absent in this fauna become very important below the depth of 105 feet, as exemplified by Planulina ornata. The two species of Discorbis given for this zone are of high frequency and are rare both above and below this zone. Archaias angulatus and Asterigerina carinata are restricted mostly to the southern profiles, being very poorly developed in the northern profiles off Panama City and Mobile. This fauna is designated as faunas $2 \mathrm{~A}$ and $2 \mathrm{~B}$ in chart 5 in order to subdivide the range of Archaias angulatus. As mentioned earlier, this species becomes very abundant in the depth range of fauna 1 .

\section{FAUNA 3 (106-180 FEET)}

Overlapping characteristics of specific ranges permit the establishment of a characteristic fauna for the depths of 106-180 feet. Planulina ornata and 
Bigenerina irregularis are the definitely diagnostic species; the remaining species which occur with this fauna are also components of other faunas. As in fauna 2, there are 3 requisites for recognition of the depth zone given for this fauna: several species (Archaias angulatus, Asterigerina carinata, Discorbis floridanus, $D$. concinnus) that were common and abundant in the zone above are rare or absent; the most important diagnostic species of this zone is Planulina ornata, although it occurs also in the next deeper zone where it accompanies the important species of fauna 4 ; and the 2 species of Hanzawaia intergrade in this depth range.

Species which are sporadic, but seemingly restricted to fauna 3, include Cibicides robertsonianus and Rotorbinella basilica. A number of rare species have much greater depth ranges as shown in charts 3-7. Bryozoans are common in the outer half of the depths assigned to this fauna, and abundant specimens of Amphistegina lessonii appear sporadically at depths mostly below 170 feet. A shallower occurrence of $A$. lessonii was noted in sample 11 off Mobile, Ala., at a depth of 108 feet. Perhaps these are being eroded from a topographic high, where they developed during times of marine transgression during the Pleistocene.

FAUNA 4 (181-250 FEET)

Diagnostic features of fauna 4 consist of the abundance of Cibicides pseudoungerianus together with Hanzawaia concentrica, Planulina ornata, Gaudryina aequa, and the Textularia conica assemblage. The $T$. conica assemblage includes this species, T. pseudotrochus, T. barrettii, and Gaudryina stavensis. This assemblage of arenaceous species makes its appearance in the zone above and continues into the upper part of the fauna 5 zone. Important species of fauna 4 which range into shallower water are Hanzawaia concentrica, Planulina. ornata, Textularia candeiana, T. mayori, and Bigenerina irregularis. Although many of the species of fauna 4 (table 2) become even more abundant in the next deeper zone, diagnostic species of fauna 5 are also present.

As mentioned under general features of faunal zonation, Amphistegina lessonii is locally abundant (10-70 percent of the fauna) in this and the following faunal zones of the southern profiles (charts 5-7). Sporadic abundant occurrences of this species indicate that it may be restricted to the fossil reef structures discussed on page 181. Many of the specimens of Amphistegina are broken and partially discolored or replaced by phosphorite(?), and this may be the reason so many specimens remained in the residues in the carbon tetrachloride separations. Some of the specimens always floated, and these were invariably fresh in appearance. Another species which may prove to be diagnostic of this depth is Marginulina advena; however, it is relatively rare. Rare species which also range downward into the next zone include Anomalina io, Bolivina dagyarius, Nonion affinis, Robulus calcar, and Textularia foliacea var. occidentalis.

FAUNA 5 (251-600 FEET)

Fauna 5 is characteristic of the upper part of the continental slope. Diagnostic species include Bolivina goësii, B. daggarius, Planulina foveolata, Robulus calcar, Uvigerina bellula, $U$. fintii, and $U$. hispido-costata. Less abundant characteristic species include Discorbis floridensis, Ehrenbergina spinea, Hanzawaia bertheloti, Höglundina elegans, Marginulinopsis densicostata, $M$. subaculeata, Spiroplectammina floridana, Pseudoclavulina constans, and Karreriella bradyi. The foregoing species represent the concentrate fraction. Amphistegina lessonii occured in many of the residues of samples from depths shallower than 350 feet in the 3 southern profiles, comprising from 10 to 70 percent of the total population there. Herein is a possible criterion for subdividing the depths of this zone; however, it is possible that a large number of specimens of this species may have been transported from the 181- to the 250-foot zone.

Species of fauna 4 are quite abundant in the depth range of fauna 5; however, the species of the latter become progressively more abundant with depth, and for this reason the depth range is subdivided into 251to 400 -foot and 400- to 600 -foot categories (table 2). Trends toward increasing abundance are not only emphasized in this way, but criteria are provided for predicting faunal positions within the zone. One of the useful lower depth-range (400-600 feet) indices is Bolivina goësii, which exhibits a median value of 7 percent in its relative proportion to the remaining benthonic species.

\section{PLANK'TONIC SPECIES}

No plankton hauls were made in conjunction with this investigation. Hence, the analyses of planktonic species are dependent solely upon the occurrence of the tests in the bottom sediments. Charts $3-7$ show several significant trends or associations. The first of these which has been noted by Lowman (1949) and by Phleger and Parker (1951) is the increase in the percentage of planktonic species with distance offshore. A second feature of importance is the association of the break in slope at the edge of the continental shelf with an abrupt increase in the percentage of planktonic species. Generally the percentage of planktonic species rises sharply from about 30 or 40 percent to 60 or 70 percent seaward across the edge of the continental shelf. A third point of significance is the progression of appearance of the tests of different planktonic species (fig. 27). Globigerinoides rubra nearly always appears 
first near the shallow end of the profiles between depths of about 70 and 100 feet. Globigerina bulloides appears next, becoming common between depths of about 100 and 160 feet and increasing more or less in frequency offshore. Glotorotalia menardii makes its appearance at about the same place as Globigerina bulloides, and then the following species appear and increase in abundance: Candeina nitida, Globigerina egger,, $G$. aequilateralis, Globigerinoides conglobata, $G$. sacculifera, Globorotalia puncticulata, G. truncatulinoides, Orbulina universa, Pulleniatina obliquiloculata, and Sphaeroidina bulloides. Finally, Globorotalia tumida makes its appearance at a depth of about 400 feet. These data suggest that living specimens of the species listed float no higher than the minimum depths indicated (Emiliani, 1954, reported similar results). Observational data by Phleger (1951, tables 2-9) bear this out. He reports living specimens of Globigerinoides rubra at the same and also shallower depths than most other planktonic species, whereas Globorotalia tumida is found living in the lower living range of most planktonic species. The fourth and last trend of general significance is the correlation of the relative abundance of planktonic species with the percentage of Foraminifera in the sediments. Wherever the percentage of tests in the sediments shows a marked increase, there is an increase in the relative percentage of planktonic species.

\section{ENVIRONMENTAL ANALYSES}

\section{GENERAL}

Many associations found in the present investigations are similar to those reported from other areas; indeed, some of the same species or their homeomorphs are reported from Japan (Hada, 1931), Germany
(Rottgardt, 1952), Trinidad (Cushman and Bronniman, 1948), and from elsewhere in the Gulf of Mexico. One of the better environmental analyses is that of Lowman (1949) in which he recognized free-floating, bottomliving stagnant(?), and bottom-living open-water categories. Planktonic species form the first category. The second is characterized by Haplophragmoides and Trochammina which are associated with Ammoastuta in brackish water and with Cyclammina and Bathysiphon in marine water, and the third is made up of the benthonic populations discussed earlier (fig. 26). The first and third categories are represented in the present study, the second is apparently absent.

\section{BRACKISH HABITAT}

In bays and harbors an important subdivision is that between open water and stagnant water. The chemical characteristics identified with stagnant environments include oxygen deficiency and the presence of toxic products as a result of organic decay. These factors are more than ample to limit the Foraminifera to those few arenaceous species which appear in such habitats (Lowman, 1949). In the open-water environment the oxygen content, although variable, is probably adequate most of the time. In this region the changes in faunas are matched against the progression in salinity values. Lowman pointed out that Ammobaculites is found in a weakly brackish environment and that Streblus, Elphidium, miliolids, and others are characteristic of strongly brackish water. Associations of Ammobaculites and Streblus in the river habitats of this investigation suggest mixed faunas due to fluctuating conditions as a result of the interaction of tidal and river currents. However, specimens of Elphidium should occur with the faunas of weakly brackish environments if this were correct.

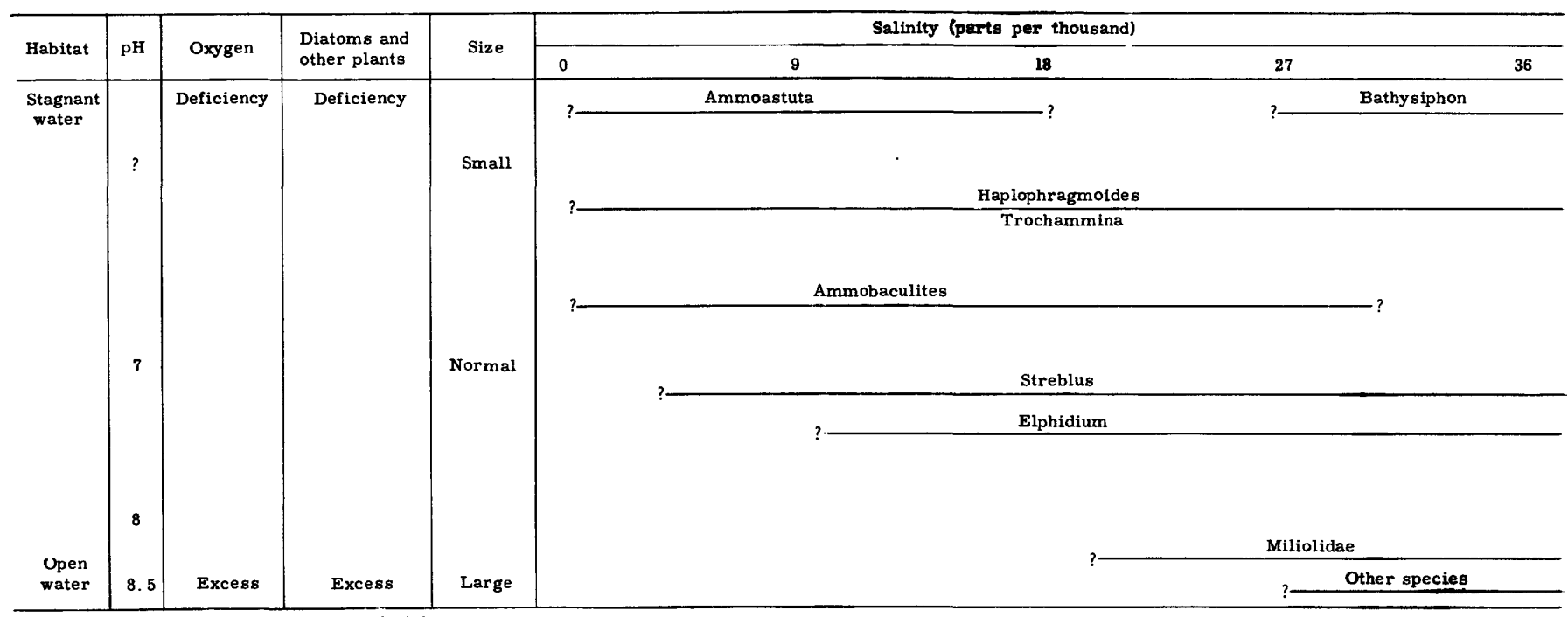

Adapted in part from data by Lowman (1949)

Figure 26.-Assemblages and ecologic factors in the river, bay, and shallow-water habitats. 
It was noted that in 1 or 2 instances the species of the open-water category were especially large and abundant adjacent to areas of high diatom production. The diatoms serve directly or indirectly as food, and their abundance may well explain the large size of the Foraminifera here. Another point of significance is that, excepting in the bay areas, the shoals exhibit a much higher percentage of Streblus tepidus (90 percent or more) than the channels.

\section{OFFSHORE AREA}

Environmental limiting factors should be more easily assessed for the offshore area than for the shallow-water areas inasmuch as the general ecology is somewhat more uniform and stable in the offshore environment. A regular procession in conditions occurs offshore with increase of depth and pressure. One of the best demonstrations of the separate effects of temperature and depth (pressure) is that of Crouch (1952). In his study of the cores of some deep basins off southern California, be found that the fauna and temperature did not change between the sill and the bottom of several deep basins, a vertical distance of several thousand feet in one case. In contrast, there is a regular succession of faunas on the open sea bottom at equivalent depths. In that environment, temperature and not depth (pressure) appears to be the main limiting factor. Temperature changes are gradational from shallow depths to the deep ocean bottom, and they seem to show a changing pattern that is reflected in the faunas. Natland (1933) noted that where the temperature changes most rapidly, the fauna changes rapidly. This correlation has been noted, also, by the author (Bandy, 1953) in the frequency charts for the offshore area of California. In the frequency charts of the present study (charts 3-7) there is an apparent correlation between temperature and faunal changes (see fig. 27). However, progressive restriciion of temperature variation may be of greatest significance in the shallower waters, whereas the reduction and continued restriction of temperature may be most significant in somewhat deeper water. Greater temperature variation near the upper part of the continental slope suggests the possibility of intermittent upwelling there (chart 7). The sudden dropoff of the lower limit of the bottom-temperature range in chart 3 between samples 7 and 8 also suggests intermittent periods of upwelling. Intermittent upwelling of colder waters may thus be most significant in two ways: in restriction of the depth ranges of stenothermal warm-water species and in providing nutrients for the phytoplankton on the outer part of the continental shelf; in this way abundant food is provided for foraminiferal populations that are adapted to lower temperatures. The $\mathrm{pH}$ of the waters of the offshore area is not considered important in limiting the distribution of the species because it ranges between the narrow limits of 7.7 and 8.2 for the most part (Sverdrup, Johnson, and

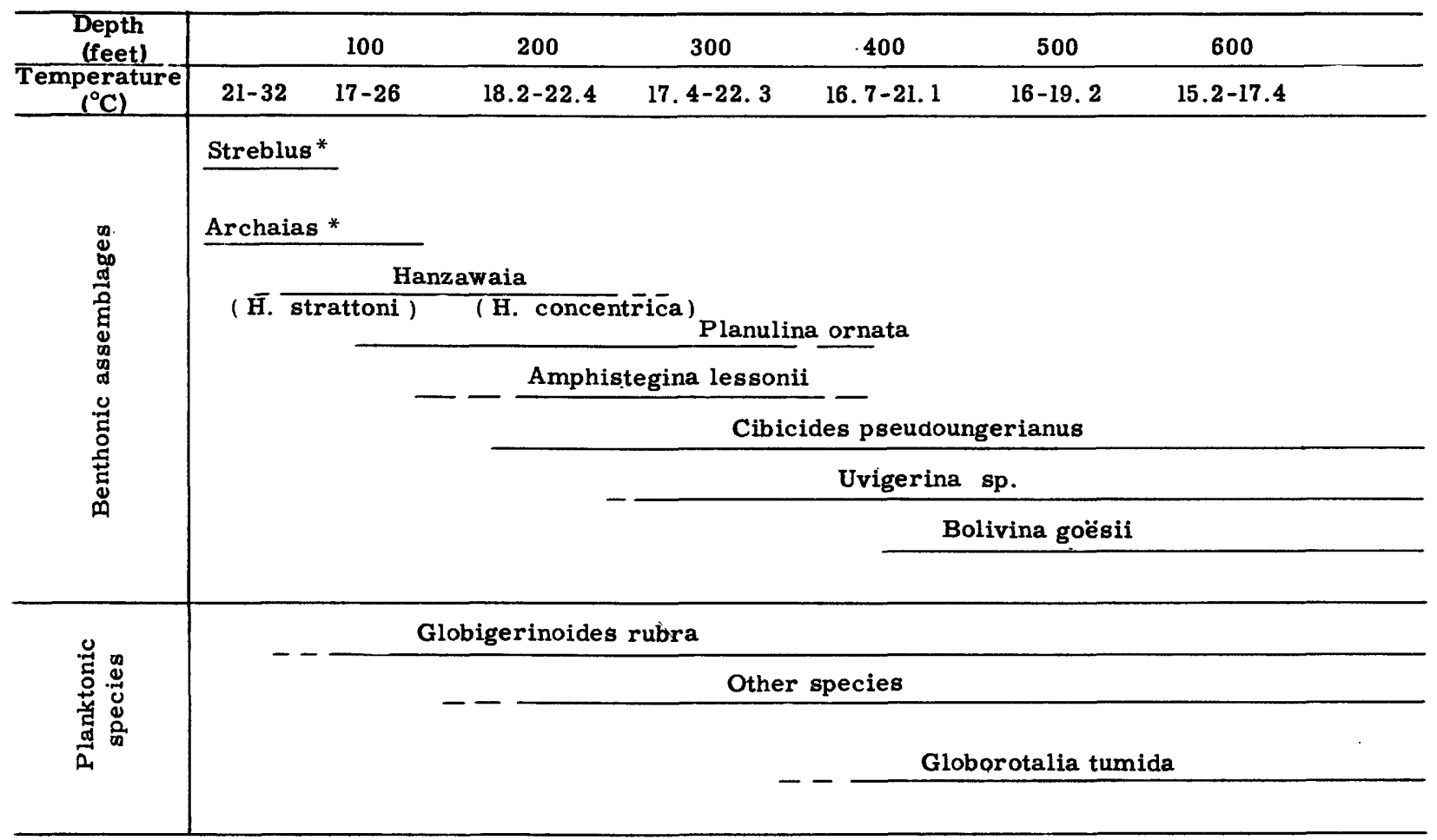

* If Streblus, a brackish-water assemblage, is present, the Archaias assemblage is generally absent. 
Fleming, 1942, p. 210). Local stagnant areas would exhibit a decrease in these values to about 7.0, perhaps less (Strom, 1936).

Variation in salinity is an important ecologic factor in the shallower waters, especially along the coasts where brackish conditions exist near the debouchments of rivers. The Streblus fauna is found generally in such areas, and its tolerance of widely varying salinities has been noted by many authors. It is known to thrive, also, in typical marine waters, as in some of the lagoons along the southern California coast; therefore, it is clearly a euryhaline fauna. This does not imply that all species of Streblus are so categorized, but only those of the $S$. tepidus type. Perhaps the most important factors in explanation of the distribution patterns of Streblus are its ability to endure great fluctuations in salinity and in the character of the sediments and associated nutrients and bottom plants. Salinity and the character of the bottom sediments appear to be two of the main factors limiting the upper depth range of Archaias. This genus is not found in depths shallower than 40 feet off the outlets of brackish bays and harbors, whereas it occurs up to the beach level in other areas such as that near Tarpon Springs. On the other hand, Archaias is not known to occur in shallow clear waters of colder regions; hence, temperature is also important.

Oxygen, nutrients, and bottom plants are closely related factors which vary with increasing depth of water in large part due to decreasing light intensity. Myers (1943) has contributed much to an understanding of the interrelationships between foraminiferal populations and bottom plants, and it should be emphasized that the successive changes occurring in the character of the latter with increasing depth would be expectably reflected in the benthonic populations of Foraminifera. Unfortunately, data on oxygen, nutrients, and bottom vegetation are not available.

Turbidity is of little importance to some of the species of Foraminifera inasmuch as the representatives of Hanzawaia of the clear waters off Florida also occur in the turbid waters off Texas and Louisiana in comparable numbers (Bandy, 1954). Other genera which are quite restricted to clear warm waters include Archaias and Asterigerina. Amphistegina tolerates some turbidity; however, it usually occurs on bottom prominences unless the waters are clear.

With the ecologic data available, temperature gradient is one of the important factors limiting the distribution of foraminiferal species; however, other factors are or may be significant, also. Some problems are raised as a result of studying the distribution patterns of some of the species of Foraminifera. One enigma involves the question of why Nonion affinis occurs at depths as shallow as 181-250 feet in the waters off Florida and specimens of this same species occur off Point Conception in abundance only at depths of 10,000 feet (Bandy, 1953). N. affinis was erroneously designated $N$. barleeanus in this earlier report. A second interesting problem involves Planulina ornata. Off San Diego, Calif., this species ranges to depths of more than 3,000 feet, whereas in this study, it becomes very rare below 400 feet. Explanations of these problems include the possibilities that the species lives in shallow water, and its tests are transported into deeper water in large numbers off San Diego; the species has adapted itself to different conditions in the 2 areas; and the 2 occurrences actually represent different species. The first and second explanations are probably in part correct; however, the solution is impossible with present data. The tests from both areas are alike and exhibit about the same amount of variability, and, in the opinion of the author, they represent a single species. They may or may not be different physiological species, but from the standpoint of the hard parts, they are indistinguishable.

\section{PALEOECOLOGICAL IMPLICATIONS}

So many of the species of this investigation range back into the history of the Gulf coastal region during early Cenozoic time that they provide not only an ideal means of interpreting environments of the later Cenozoic but also an approach toward extrapolating even further into the geologic past of Florida. This section is not an attempt to present a complete analysis of the paleoecology of the later Cenozoic of Florida, but only an effort to exemplify how investigations of this kind may be used to express quantitative environmental changes of the geologic past. Cooke (1945) has presented the best stratigraphic and paleogeographic study of Florida, and he and others have met with difficulty in using Foraminifera for stratigraphic correlation purposes in Florida. These difficulties were recently expressed by Schroeder and Bishop (1953), who attempted to reevaluate the foraminiferal data presented by Cole (1931) and Cushman and Ponton (1932). In table 3 are some of the species assigned to the faunal zones by Cushman and Ponton. Ecology of the modern representatives or homeomorphs of these species is used as a basis for reconstructing depth and temperature trends in the later Cenozoic of Florida (fig. 28). It is assumed that the water temperatures of the Gulf of Mexico have been essentially the same as those of today. If not, the picture presented herein might be modified somewhat.

According to the foregoing foraminiferal species, it would seem that the early Miocene (Tampa limestone) was deposited in less than 100 feet of water, probably 
TABLE 3.-Foraminifera in selected formations of the Miocene, Pliocene, and Pleistocene of Florida

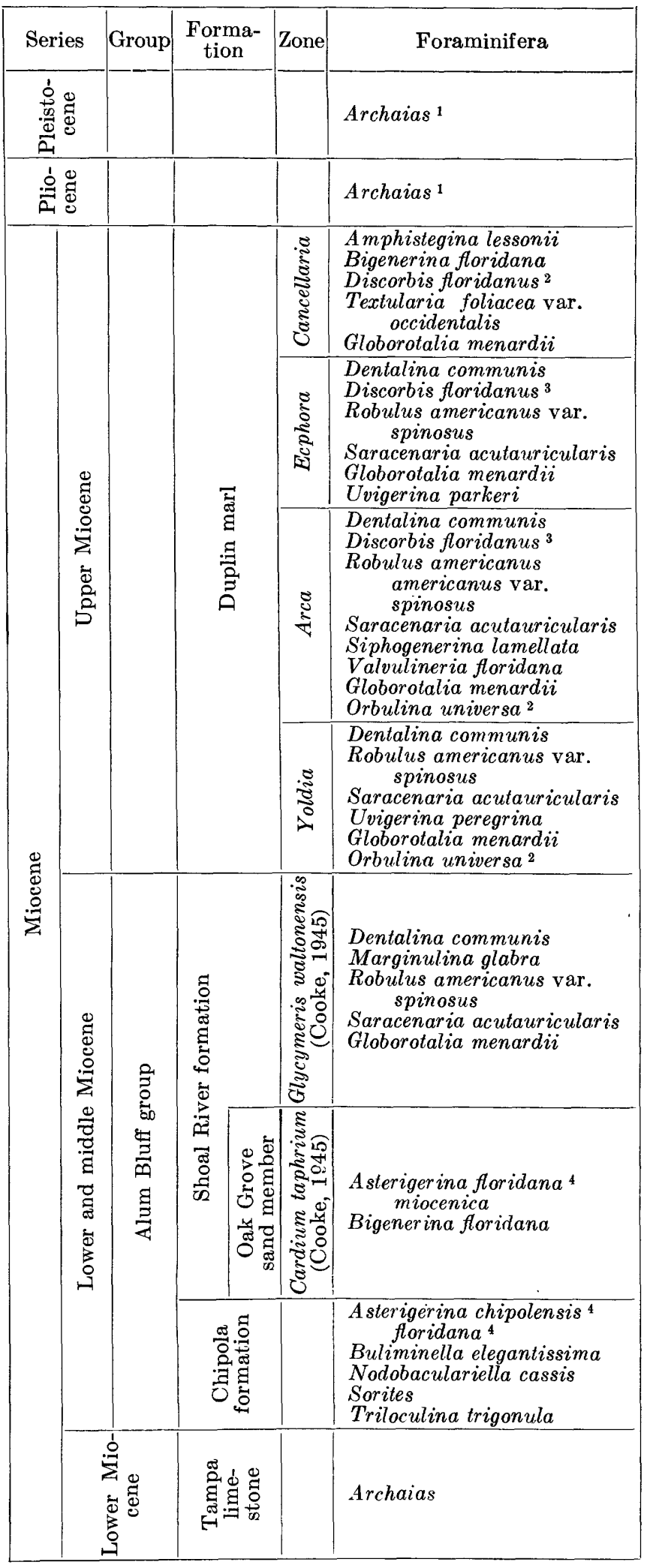

1 Marine formations. ${ }^{2}$ Common. ${ }^{3}$ Rare.

4 These species were originally described under Amphistegina by Cushman and in Asterigerina. less than 40 feet; the lower Miocene (Chipola formation) was deposited at depths between 40 and 100 feet; and the late Miocene (Duplin marl) is represented by a cycle of deepening and subsequent shoaling through the zonal sequences from the Cardium zone to the Pliocene. The major depth attained was probably between 250 and 600 feet. The presence of Valvulineria and Uvigerina suggest these depths. During Pliocene and Pleistocene times the Archaias fauna characterized many of the marine sediments which are, therefore, considered to have been deposited in less than 100 feet of water. The detailed picture may actually be much more complex; for example, foraminiferal lists of Schroeder and Bishop (1953) indicate that part of the Hawthorn formation of early and middle Miocene age was deposited in deeper water (250-600 feet) than the Chipola, and also a part of the Pliocene faunas of Cole (1931) represent a Streblus facies which suggests shallow water and variable salinity. Frequency analyses should be made of all of the various facies of the middle and later Cenozoic before the

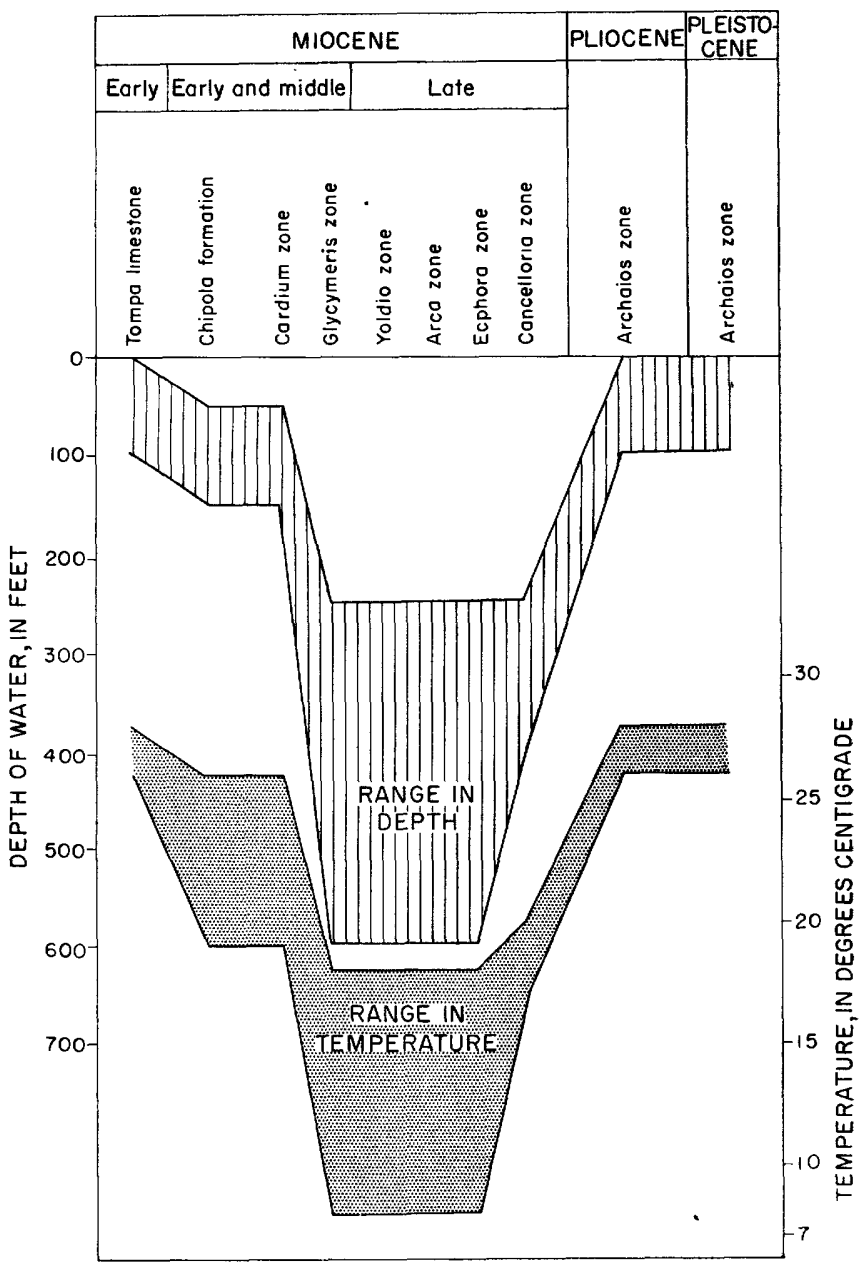
Figure 28.-Depth and temperature variations during Miocene to Pleistocene time
in northern Florida. 
foraminiferal evidence in the literature will have great ecologic significance. The temperature curve in figure 28 is not indicative of climatic change, but of cooling due to deepening of the seas followed by shoaling of the seas and resulting higher temperatures. Gardner (1926, p. 101) suggested reduced temperatures following the deposition of the Chipola; however, she indicates shoaling following Chipola time in contrast to the deepening indicated herein.

Two particular problems of the Cenozoic stratigraphy of Florida are emphasized by investigations such as this: whether there are as many erosional unconformities as have been suggested, and whether biofacies maps of successive stratigraphic units of Florida should exhibit ecologic suites comparable to those indicated in this investigation. In amplification of the first problem, proposed evidence of an unconformity between the Hawthorn formation and the upper Miocene strata is suspect because there is little or no evidence of shoaling in the upper part of the Hawthorn formation. According to the foraminiferal data, this formation was deposited at depths greater than 200 feet. Similarly, the upper Miocene strata represent about the same conditions. Further analyses may either corroborate or otherwise explain this condition. The second problem involving biofacies studies of the stratigraphic units of Florida should reveal a series of ecologic zones paralleling the former shorelines, and these would duplicate their modern counterpart in a general way. Because of homotaxis, very careful speciation and identification of varieties will be necessary in order to develop stratigraphic indices that are dependable.

\section{CONCLUSIONS}

Brackish-water species of Foraminifera in the bays of Florida are cosmopolitan in that they are found, also, in many of the brackish-water areas of the world, especially the coastal regions of the Gulf of Mexico and the Caribbean Sea. This shallow-water environment is subdivided into shoals and channels, and these are separated into inner, intermediate, and outer bay areas. The lower reaches of some rivers are also represented, and these together with the inner shoals are characterized by very high frequencies of Streblus and Ammobaculites. The inner channel and bay habitats exhibit an abundance of Streblus and Elphidium, and the intermediate and outer harbor and bay areas have an abundance of these two genera together with abundant miliolids and rare marine species. The intermediate and outer shoals are marked by the presence of very high frequencies of Streblus and few if any arenaceous species. The faunal pattern is considered to correlate with the salinity gradient generally as follows: 1-9 parts per thousand, Ammobaculites and Streblus; 9-27 parts per thousand, Ammobaculites, Streblus, and Elphidium; 27-34 parts per thousand, Streblus, Elphidium, Miliolidae, and other rare marine species. The stagnant brackish habitat is not represented by the samples of this investigation; however, from data compiled by others it is noted that foraminiferal assemblages are almost totally different, and they, too, exhibit changes that correlate with the salinity gradient. Temperature variation is an important factor in restricting the faunas of shallow-water areas to eurythermal species. Low $\mathrm{pH}$ values of rivers constitute a restrictive factor to procelaneous and hyaline species. Variation in food is probably very important, but data of this type are unavailable; however, it was noted that unusually large specimens of Foraminifera occur adjacent to areas of extremely high diatom production. The percentage of tests in the sediment was found to be highest in the moderately to strongly brackish waters of channels and open bays, whereas the lowest percentages were found in the weakly brackish areas of the river and shoal habitats. The exclusion of porcelaneous and hyaline species from the latter explains the reduction in percentage.

Five general faunas are indicated for the offshore area between depths of 8 and 600 feet: (1) Streblus fauna, 8-40 feet, off brackish bays; (2) Archaias fauna, 8-105 feet, in normally saline waters, and Asterigerina carinata fauna including Hanzawaia strattoni, 41-105 feet; (3) Planulina ornata fauna, 106-180 feet; (4) Cibicides pseudoungerianus fauna, 181-250 feet; and (5) Uvigerina fauna, 251-600 feet (deep end of sampled profiles). In fauna 5, Bolivina goësii becomes significant below a depth of 400 feet, affording a means for subdividing the fifth depth zone.

Off western Florida, an Amphistegina assemblage occurs locally between depths of 170 and 350 feet on the upper part of the continental slope. This assemblage is almost invariably associated with fossil reefs of Bryozoa and calcareous algae.

Ecologic interpretations indicate that both the progressive restriction of temperature range and reduction of temperature are significant as limiting factors in the offshore area. Upwelling of colder waters is indicated on the outer part of the continental shelf by sudden drops of the lower limit of the bottom temperature. Variations in salinity are mostly significant in the shallow coastal waters; otherwise, this factor is nearly stable in deeper waters and is relatively unimportant. Variation in $\mathrm{pH}$ is also quite restricted in the open sea and is considered to be of little consequence. Turbidity is important in the shallower waters, inhibiting the development of the Archaias assemblage in some areas. Other species such as Hanzawaia strattoni and $H$. concentrica occur in both 
clear and turbid waters and are clearly tolerant of considerable turbidity. Factors such as food, nutrients, and bottom plant distribution are considered important, but data for these are lacking.

Percentages (weight) of Foraminifera in the bottom sediments increase from less than 1 percent near shore to about 2 percent on the outer part of the continental shelf. There is a rapid increase on the upper part of the continental slope where the tests of planktonic species increase in frequency. There is also an increase in the number of benthonic species from about 20 in the nearshore area to more than 50 at a depth of 600 feet. Hyaline species are abundant over all of the offshore region; however, porcelaneous species have the greatest frequency in less than 100 feet of water on shell bottoms, and arenaceous species, which comprise less than 10 percent of the benthonic species generally, amount to as much as 20 percent or more in many places near the edge of the continental shelf.

There are four points of significance regarding the planktonic species: a general increase occurs in the percentage of planktonic tests offshore; an abrupt increase is observed in this percentage from about 35 to 65 percent in crossing the edge of the continental shelf; there is a progression of appearance of the planktonic species, that is, Globigerinoides rubra appears at depths of between 70 and 100 feet, most of the remaining species appear between 100 and 160 feet, and Globorotalia tumida makes its appearance at a depth of about 400 feet; and increase in the percentage of planktonic species correlates generally with an increase in the weight percentage of Foraminifera in the sediment.

Paleoecological implications of this investigation are exemplified by a summary analysis of published foraminiferal data on the Miocene, Pliocene, and Pleistocene of northern Florida. Beginning with the early Miocene, the water depth was between 0 and 100 feet. In the middle Miocene it was somewhat deeper and at the beginning of the late Miocene it became even deeper, attaining depths of $250-600$ feet. In the later part of the Miocene, shoaling began and continued into the Pliocene in most areas. Marine Pliocene and Pleistocene faunas represent depositional conditions such as those prevailing between 0 and 100 feet of depth off the present coast. Exceptions to this general trend occur southward where the Hawthorn formation of early and middle Miocene time represents a deeper water facies than its time equivalent to the north. There are also some examples of brackish-water facies in the Pliocene.

\section{FAUNAL REFERENCE LIST}

An alphabetized reference list of the species of Foraminifera studied during this work is given below. The original and sometimes one or more subsequent references are given for each of the species. Where changes in classification have been made, the reasons for these are discussed briefly. The primary object of this list is to facilitate reference to original sources and to systematic treatises. Illustrations of those species which are not figured herein will be found in the references given. The species are systematically arranged on the plates so that related species are together. The figures were made by Miss Mary E. Taylor, and the types are catalogued and deposited in the U.S. National Museum, Washington, D. C. A duplicate set is a gift to the Hancock Foundation, University of Southern California, Los Angeles, Calif.

Ammobaculites exiguus Cushman and Bronniman, 1948, Cushman Lab. Foram. Research Contr., v. 24, p. 38, pl. 7, figs. 7, 8. Gulf of Paria, Trinidad, in 0-2 fathoms.

This paper, pl. 30, fig. 2.

Ammobaculites exilis Cushman and Bronniman, 1948, idem, p. 39, pl. 7, fig. 9. Gulf of Paria, Trinidad, in 0-2 fathoms.

This paper, pl. 30, fig. 3. Most of the specimens were broken.

Ammobaculites salsus Cushman and Bronniman, 1948, idem, p. 16, pl. 3, figs. 7-9. Brackish water, west coast of Trinidad.

This paper, pl. 30, fig. 4.

Amphistegina lessonii D'Orbigny, 1826, Annales sci. nat., sér 1, tome 7, p. 304, Modeles, no. 98, L'Ile-de-France (Mauritius).

Phleger and Parker, 1951, Geol. Soc. America Mem. 46, pt. 2 , p. 26 , pl. 13, figs. 13,14 ; pl. 14, fig. 1 . Recent, Gulf of Mexico.

Angulogerina bella Phleger and Parker, 1951, Geol. Soc. America Mem. 46, pt. 2, p. 12, pl. 6, figs. 7-8. Gulf of Mexico, mostly between 50 and 120 meters.

The occurrence of this species in the present investigation accorded with the indicated range given for the type.

Anomalina io (Cushman), 1931, U. S. Natl. Mus. Bull. 104, p. 125, pl. 23, figs. 1, 2. Off Fowey Light, Florida, in 40 fathoms.

This paper, pl. 31, fig. 7 .

Various authors have followed Cushman in assigning this species to Cibicides; however, the dorsal spire is concealed, and it tends to be bilaterally symmetrical and falls well within the definition of the genus Anomalina. The present author considers that Anomalinoides Brotzen (1942, Sver. Geol. Unders., Sweden, Avh., ser. $\mathrm{C}$, no. 451) is a junior synonym of D'Orbigny's genus.

Archaias angulatus (Fichtel and Moll), 1798, Testacea microscopica aliaque, minuta ex generibus Argonauta et Nautilus, Wien, Osterreich, p. 113, pl. 22, figs. a-e. Recent, Arabian Sea.

Cushman, J. A., 1930, U. S. Natl. Mus. Bull. 104, pt. 7, p. 46 , pl. 16, figs. 1-3; pl. 17, figs. 3-5.

Growth sequences indicate that this species is quite variable, depending on its size. Other species that have been established for variations of this species are included in the present concept of $A$. angulatus as illustrated by Cushman in the reference given above. 
Articulina sagra D'Orbigny, 1839, Foraminifères, in Ramon de la Sagra, Histoire physique, politique et naturelle de l'Ile de Cuba, p. 183 (plates published separately), v. 8, pl. 9, figs. 23-26. Recent, Cuba.

Astacolus ovatus Galloway and Heminway, 1941, New York Acad. Sci., Sci. Survey Puerto Rico and Virgin Islands, v. 3, pt. 4, p. 334, pl. 8, fig. 10. Upper Oligocene, Puerto Rico.

Asterigerina carinata D'Orbigny, 1839, Foraminifères, in Ramon de la Sagra, Histoire physique, politique et naturelle de l'Ile de Cuba, p. 118 (plates published separately), v. 8, pl. 5, fig. 25; pl. 6, figs. 1-2. Recent, Cuba and Jamaica. Bandy, O. L., 1954, U. S. Geol. Survey Prof. Paper 254-F, pl. 31, fig. 5. Recent, Gulf of Mexico.

Bathysiphon sp. Fragments of this genus were found in a few samples.

Bigenerina irregularis Phleger and Parker, 1951, Geol. Soc. America Mem. 46, pt. 2, p. 4, pl. 1, figs. 16-21. Recent, Gulf of Mexico.

Bandy, 1954, U. S. Geol. Survey Prof. Paper 254-F, pl. 29, figs. 8, 9. Recent, Gulf of Mexico.

Bolivina daggarius Parker, 1955, Cushman Found. Foram. Research, Contr., v. 6, pt. 1, p. 52. Recent, Gulf of Mexico.

This paper, pl. 31, fig. 9.

Bolivina fragilis Phleger and Parker, 1951, idem, p. 13, pl. 6, figs. 14, 23, 24a, 24b. Recent, Gulf of Mexico.

Bolivina goësii Cushman, 1922, U. S. Natl. Mus. Bull. 104, pt. 3, p. 34, pl. 6, fig. 5. Recent, Atlantic Ocean.

Phleger and Parker, 1951, Geol. Soc. America Mem. 46, pt. 2, p. 13, pl. 6, fig. 17. Recent, Gulf of Mexico.

Bolivina pulchella (D’Orbigny) var. primitiva Cushman, 1930, Florida Geol. Survey Bull. 4, p. 47, pl. 8, figs. 12a, 12b. Choctawhatchee marl, Florida.

Phleger and Parker, 1951, Geol. Soc. America Mem. 46, pt. 2, p. 14, pl. 7, fig. 3. Recent, Gulf of Mexico.

Bolivina striatula Cushman, 1922, Carnegie Inst. Washington Pub. 311, p. 27, pl. 3, fig. 10 . Recent, Tortugas region.

Bandy, 1954, U. S. Geol. Survey Prof. Paper 254-F, pl. 31, fig. 9. Recent, Gulf of Mexico.

Bolivina subaenariensis Cushman var. mexicana Cushman, 1922, U. S. Natl. Mus. Bull. 104, pt. 3, p. 47, pl. 8, fig. 1 . Recent, Gulf of Mexico.

This paper, pl. 31, fig. 10.

Buccella hannai (Phleger and Parker), 1951, Geol. Soc. America Mem. 46, pt. 2, p. 21, pl. 10, figs. 11-14. Recent, Gulf of Mexico.

This species is the genotype for Buccella Anderson, 1952.

Bulimina marginata D’Orbigny, 1826, Annales sci. nat. sér. 1, tome 7, p. 269, pl. 12, figs. 10-12. Recent, Rimini, Italy.

Phleger and Parker, 1951, Geol. Soc. America Mem. 46, pt. 2, p. 16, pl. 7, figs. 27, 28. Recent, Gulf of Mexico.

Buliminella elegantissima (D'Orbigny), 1839, Voyage dans l'Amérique méridionale, v. 5, Foramiféres, pt. 5, p. 51, pl. 7, figs. 13, 14.

Phleger and Parker, 1951, Geol. Soc. America Mem. 46, pt. 2, p. 17, pl. 8, figs. 3, 4. Recent, Gulf of Mexico.

Cancris sagra (D'Orbigny), 1839, Foraminifères, in Ramon de la Sagra, Histoire physique, politique et naturelle de l'Ile de Cuba, p. 77, pl. 5, figs. 13-15. Recent, Cuba and Jamaica.

andy, 1954, U. S. Geol. Survey Prof. Paper 254-F, pl. 30, fig. 9. Recent, Gulf of Mexico.
Candeina nitida D'Oribigny, 1839, Foraminifères, in Ramon de la Sagra, Histoire physique, politique et naturelle de l'Ile de Cuba, p. 108, pl. 2, figs. 27-28. Recent, Cuba and Jamaica.

Cushman, 1941, Amer. Jour. Sci., v. 239, pl. 1, fig. 1. Recent, Bartlett Deep.

Cassidulina curvata Phleger and Parker, 1951, Geol. Soc. America Mem. 46, pt. 2, p. 26, pl. 14, fig. 5. Recent, Gulf of Mexico.

This species was very abundant in many of the samples near the outer ends of the profiles, and it was accompanied by small similar species, mainly $C$. laevigata D'Orbigny and $C$. laevigata var. carinata Cushman. It is doubtful if the Gulf of Mexico specimens assigned to $C$. laevigata are properly assigned. The Gulf of Mexico specimens are figured in the paper by Phleger and Parker.

Cibicides deprimus Phleger and Parker, 1951, idem, p. 29, pl. 15, figs. 16, 17. Recent, Gulf of Mexico.

Cibicides pseudoungerianus (Cushman), 1922, U. S. Geol. Survey Prof. Paper 129-E, p. 97, pl. 20, fig. 9. Oligocene, Mississippi.

This paper, pl. 31 , fig. 8 .

A comparison of the specimens of this investigation with the types in the U. S. National Museum indicate that they fall within the scope of this species.

Cibicides robertsonianus (H. B. Brady), 1881, Quart. Jour. Micros. Soc., v. 21, p. 65.

Brady, 1884 Challenger Rept., Zoology, v. 9, p. 664, pl. 95, figs. 4a-c.

Phleger and Parker, 1951, Geol. Soc. America Mem. 46, p. 31, pl. 16, figs. 10-13. Recent, Gulf of Mexico.

Dentalina communis (D'Orbigny), 1826, Annales sci. nat., sér. 1, tome 7, p. 254. Recent, Adriatic Sea.

Cushman, 1923, U. S. Natl. Mus. Bull. 104, pt. 4, p. 75-76, pl. 12, figs. 3, 4, 15-17. Recent, Atlantic Ocean.

Dimorphina sp. Only 2 or 3 specimens of this genus were found. Discorbis concinnus (H. B. Brady), 1884, Challenger Rept., Zoology, v. 9, p. 646, pl. 90, figs. 7-8. Recent, tropical seas.

This paper, pl. 31, fig. 4 .

Discorbis floridanus Cushman, 1922, Carnegie Inst. Washington Pub. 311, p. 39, pl. 5, figs. 11-12. Recent, Dry Tortugas Islands.

Bandy, 1954, U. S. Geol. Survey Prof. Paper 254-F, pl. 31, fig. 1. Recent, Gulf of Mexico.

Discorbis floridensis Cushman, 1931, U. S. Natl. Mus. Bull. 104, pt. 8, p. 17, pl. 3, figs. 3-5. Recent, Atlantic Ocean.

This paper, pl. 31 , fig. 5 .

Ehrenbergina spinea Cushman, 1935, Smithsonian Misc. Coll., v. 91, no. 21, p. 8 , pl. 3, figs. 10, 11. Recent, off Puerto Rico.

Phleger and Parker, 1951, Geol. Soc. America Mem. 46, pt. 2, p. 27, pl. 14, fig. 18. Recent, Gulf of Mexico.

Elphidium advenum (Cushman), 1922, Carnegie Inst. Washington Pub. 311, p. 56, pl. 9, figs, 11-12. Recent, Dry Tortugas Islands.

This paper, pl. 30, fig. 18 .

Specimens of this study were found to agree perfectly with the types of this species.

Elphidium discoidale (D'Orbigny), 1839, in Ramon de la Sagra, Histoire physique, politique et naturelle de l'Ile de Cuba, p. 56, pl. 6, figs. 23-24. Recent, Cuba and Jamaica.

Bandy, 1954, U. S. Geol. Survey Prof. Paper 254-F, pl. 30, fig. 4. Recent, Gulf of Mexico. 
Elphidium gunteri Cole, 1931, Florida Geol. Survey Bull. 6, p. 34, pl. 4, figs. 9, 10. Pliocene, Florida.

This paper, pl. 30, fig. 19 .

Some specimens of the variety $E$. gunteri var. galvestonense Kornfeld were included in the counts of this species.

Elphidium mexicanum Kornfeld, 1931, Stanford Univ., Dept. Geology, Contr., v. 1, no. 3, p. 89, pl. 16, figs. 1, 2. Recent, Texas and Louisiana.

This paper, pl. 30, fig. 20.

Elphidium poeyanum (D'Orbigny), 1839, in Ramon de la Sagra, Histoire physique, politique et naturelle de l'Ile de Cuba, Foraminifères, p. 55, pl. 6, figs. 25, 26. Recent, Cuba and Jamaica.

Bandy, 1954, U. S. Geol. Survey Prof. Paper 254-F, pl. 30, fig. 6. Recent, Gulf of Mexico.

Elphidium rugulosum Cushman and Wickenden, 1929, U. S. Natl. Mus. Proc. 2780, v. 75, art. 9, p. 7, pl. 3, fig. 8. Recent, 10-20 fathoms off Juan Fernandez Island, Chile, This paper, pl. 30, fig. 21.

Eponides antillarum (D'Orbigny), 1839, in Ramon de la Sagra, Histoire physique, politique et naturelle de l'Ile de Cuba, p. 75, pl. 5, figs. 4-6. Recent, Cuba and Jamaica.

Bandy, 1954, U. S. Geol. Survey Prof. Paper 254-F, pl. 30, fig. 8.

Frondicularia sagittula Vanden Broeck, 1876, Annales Soc. Belgique Micros., v. 2, p. 113, pl. 2, figs. 12, 14 . Recent, British West Indies.

Cushman, 1923, U. S. Natl. Mus. Bull. 104, pt. 4, p. 143, pl. 21, fig. 2. Recent, Gulf of Mexico.

Gaudryina aequa Cushman, 1947, Cushman Lab. Foram. Research, Contr., v. 23, pt. 4, p. 87, pl. 18, figs. 18-21. Recent, South Carolina.

Phleger and Parker, 1951, Geol. Soc. America Mem. 46, pt. 2, p. 6, figs. 11, 12 . Recent, Gulf of Mexico.

The specimens figured by Phleger and Parker are quite typical of the species and should be identified as such.

Gaudryina stavensis Bandy, 1949, Bull. Am. Paleontology, v. 32 , no. 131 , p. 29 , pl. 3 , fig. 8 . Oligocene, Alabama.

This paper, pl. 30 , fig. 1 .

The specimens are remarkably similar to the types of this species. Both are quite distinctly triserial in the early portion of the test and the roughness of the surface is somewhat variable. The specimens may have been reworked from the Eocene.

Glandulina comatula (Cushman), 1923, U. S. Natl. Mus. Bull. 104 , pt. 4, p. 83, pl. 14, fig. 5. Recent, Gulf of Mexico.

Phleger and Parker, 1951, Geol. Soc. America Mem. 46, pt. 2, p. 10, pl. 5, figs. 7-9. Recent, Gulf of Mexico.

The type of Glandulina (G. laevigata) as sectioned and presented by D'Orbigny is strictly uniserial; hence, topotypes which are otherwise can hardly suffice for interpretation of the generic characters of Glandulna. The author considers the genus Pseudoglandulina Cushman to be a junior synonym of Glandulina. The types are well figured in Ellis and Messina (Catalogue of Foraminifera, 1940-54) and the synonymy presented by Galloway (1933) is excellent.

Globigerina bulloides D'Orbigny, 1826, Annales sci. nat., sér. 1, tome 7, p. 277, Modèles, no. 17. Recent, Adriatic Sea.

Phleger and Parker, 1951, Geol. Soc. America Mem. 46, pt. 2, p. 34, pl. 19, figs. 6, 7. Recent, Gulf of Mexico.
Globigerina eggeri Rhumbler, 1900, Nordische Plankton, pt. 14 Foraminiferan, p. 19, fig. 20. Recent, Atlantic and Pacific Oceans.

Phleger and Parker, 1951, Geol. Soc. America Mem. 46, pt. 2, p. 34, pl. 19, figs. 8,9 . Recent, Gulf of Mexico.

Globigerinella aequilateralis (H. B. Brady), 1879, Quart. Jour. Micros. Sci., v. 19, p. 71.

Brady, 1884, Challenger Rept., Zoology, v. 9, p. 605, pl. 80, figs. 18-21.

Phleger and Parker, 1951, Geol. Soc. America Mem. 46, pt. 2, p. 35, pl. 19, fig. 14. Recent, Gulf of Mexico.

Globigerinoides conglobata (H. B. Brady), 1879, Quart. Jour. Micros. Sci., v. 19 , p. 72 .

Brady, 1884, Challenger Rept., Zoology, v. 9, p. 603, pl. 80, figs. 1-5; pl. 82, fig. 5.

Phleger and Parker, 1951, Geol. Soc. America Mem. 46, pt. 2, p. 35, pl. 19, fig. 15. Recent, Gulf of Mexico.

Globigerinoides rubra (D'Orbigny), 1839, in Ramon de la Sagra, Histoire physique, politique et naturelle de l'Ile de Cuba, p. 82, pl. 4, figs. 12-14. Recent, Cuba and Jamaica.

Bandy, 1954, U. S. Geol. Survey Prof. Paper 254-F, pl. 31, fig. 6. Recent, Gulf of Mexico.

Globigerinoides sacculffera (H. B. Brady), 1877, Geol. Mag., v. 4, p. 535 .

Brady, 1884, Challenger Rept., Zoology, v. 9, p. 604, pl. 80, figs. 11-17; pl. 82, fig. 4 . Recent, near New Guinea.

Phleger and Parker, 1951, Geol. Soc. America Mem. 46, pt. 2, p. 35, pl. 19, figs. 17, 18. Recent, Gulf of Mexico.

Globorotalia menardii (D'Orbigny), 1826, Annales sci. nat., v. 7, p. 273; Modèles, no. 10 .

Phleger and Parker, 1951, Geol. Soc. America Mem. 46, pt. 2, p. 36, pl. 20, figs. 1,2. Recent, Gulf of Mexico.

Globorotalia puncticulata (D'Orbigny), 1832, in Deshayes, G. P., Encyclopedia Methodique, Histoire naturelle des vers. Paris, tome 2, pt. 2, p. 170.

Fornasini, 1898, Paleont. Italica, v. 4, p. 210, tf 5, "Figure inedite di d'Orbigny."

This paper, pl. 31 , fig. 1 .

Globorotalia truncatulinoides (D'Orbigny), 1839, in Barker-Webb and Berthelot, Histoire Naturelle Iles Canaries, v. 2, pt. 2, "Foraminifères", p. 132, pl. 2, figs. 25-27. Recent, Canaries.

Phleger and Parker, 1951, Geol. Soc. America Mem. 46, pt. 2, p. 36, pl. 20, figs. 3-7. Recent, Gulf of Mexico.

Globorotalia tumida (H. B. Brady), 1877, Geol. Mag., v. 4, p. 294.

Brady, 1884, Challenger Rept., Zoology, v. 9, p. 692, pl. 103, figs. 4-6. Recent, near New Guinea.

Phleger and Parker, 1951, Geol. Soc. America Mem. 46, pt. 2, p. 36, pl. 20, figs. 14, 15. Recent, Gulf of Mexico.

Guttulina australis (D'Orbigny), 1839, Voyage dans l'Amérique méridionale, v. 5, pt. 5 , Foraminifères, p. 60 , pl. 1 , figs. 1-4.

Bandy, 1954, U. S. Geol. Survey Prof. Paper 254-F, pl. 29, fig. 7. Recent, Gulf of Mexico.

Guttulina regina Cushman is a junior synonym of G. australis. For additional information about this synonymy see Cushman and Ozawa (1930, p. 32).

Gypsina vesicularis (Parker and Jones), 1860, Ann. Mag. Nat. History, ser. 3, v. 6, p. 31, no. 5. Recent, Australia.

Phleger and Parker, 1951, Geol. Soc. America Mem. 46, pt. 2, p. 33, pl. 19, fig. 4. Recent. Gulf of Mexico. 
Hanzawaia bertheloti (D'Orbigny), 1839, in Barker-Webb and Berthelot, Histoire Naturelle Iles Canaries, v. 2, pt. 2, Foraminifères, p. 135, pl. 1, figs. 28-30.

This paper, pl. 31 , fig. 6 .

The genus Hanzawaia was proposed in 1944 (Asano) for species such as this one with the dorsal spire more or less covered with flaplike extensions of the last whorl. The genus Cibicidina (Bandy, 1949) is a junior synonym of this genus.

Hanzawaia concentrica (Cushman), 1918, U. S. Geol. Survey Bull. 676, p. 64, pl. 21, fig. 3, Choctawhatchee marl, Florida.

Phleger and Parker, 1951, Geol. Soc. America Mem. 46, pt. 2, p. 29, pl. 15, figs. 14, 15 . Recent, Gulf of Mexico.

Hanzawaia strattoni (Applin), 1925, Am. Assoc. Petroleum Geologists Bull., v. 9, no. 1, p. 99, pl. 3, fig. 3. Miocene, Louisiana.

Bandy, 1954, U. S. Geol. Survey Prof. Paper 254-F, pl. 31, fig. 4. Recent, Gulf of Mexico.

Haplophragmoides mexicana Kornfeld, 1931, Stanford Univ., Dept. Geology, Contr., v. 1, no. 3, p. 83, pl. 13, fig. 4. Recent, littoral zone of Texas and Louisiana.

Bandy, 1954, U. S. Geol. Survey Prof. Paper 254-F, pl. 29, fig. 6. Recent, Gulf of Mexico.

Höglundina elegans (D’Orbigny), 1826, Annales sci. nat., v. 7, p. 276, no. 54 .

Phleger and Parker, 1951, Geol. Soc. America Mem. 46, pt. 2, p. 22, pl. 12, fig. 1. Recent, Gulf of Mexico.

Karreriella bradyi (Cushman), 1911, U. S. Natl. Mus. Bull. 71, pt. 2, p. 67, text figs. 107a-c. Recent, Pacific Ocean.

Phleger and Parker, 1951, Geol. Soc. America Mem. 46, pt. 2, p. 6, pl. 3, fig. 4. Recent, Gulf of Mexico.

Lagena spp. Occasional specimens of this genus were of little value in this investigation. They are plotted together in the frequency graphs.

Lagenonodosaria scalaris (Batsch), 1791, Sechs Kupfertafeln mit Conchylien des Seesandes, p. 5, pl. 2, fig. 4.

This paper, pl. 30, fig. 16.

Lingulina carinata D'Orbigny, 1926, Annales sci. nat., v. 7, p. 257, no. 1; Modèles, no. 26.

Cushman, 1923, U. S. Natl. Mus. Bull. 104, pt. 4, p. 95, pl. 19, figs. 1, 2. Recent, off Florida.

Loxostomum mayori (Cushman), 1922, Carnegie Inst. Washington Pub. 311, v. 7, p. 27, pl. 3, figs. 5, 6. Recent, off Florida.

This paper, pl. 31, fig. 11 .

Loxostomum subspinescens (Cushman), 1922, U. S. Natl. Mus. Bull. 104, pt. 3 , p. 48 , pl. 7 , fig. 5 .

This paper, pl. 31, fig. 12 .

This species seems to be rather variable in the spinose character of the walls. The larger individuals are characterized almost entirely by the terminal aperture, and the species is placed, therefore, in Loxostomum rather than Bolivina, its original designation.

Marginulina advena (Cushman), 1923, U. S. Natl. Mus. Bull. 104, pt. 4, p. 134, pl. 39, figs. 1-4. Recent, off Florida.

This paper, pl. 30 , fig. 15 .

This species was originally placed in Vaginulina by Cushman. It is compressed in the early part, but the adult is nearly always oval in cross section. It is placed, therefore, in Marginulina. The types were examined in the U.S. National Museum, and they form the basis for the change. The variation observed in the type specimens is considered to be the result of dimorphism.
Marginulina hantkeni Bandy, 1949, Bull. Am. Paleontology, v. 32, no. 131, p. 46, pl. 6, fig. 9. Eocene, Alabama.

Some specimens occur in the present investigation that are very similar to this species. As noted in the original publication, $M$. hantkeni was a new name for the homonym $M$. subbullata Hantken.

Marginulinopsis densicostata Thalmann, 1937, Eclogae Geol. Helvetiae, Lausanne, Suisse, v. 30, p. 347, pl. 21, fig. 2. Recent, West Indies.

Marginulinopsis subaculeata (Cushman), 1923, U. S. Natl. Mus. Bull. 104, pt. 4, p. 123, pl. 34, fig. 2. Recent, Gulf of Mexico.

This paper, pl. 30, fig. 14 .

Nodobaculariella atlantica Cushman and Hanzawa, 1937, Cushman Lab. Foram. Research Contr., v. 13, pt. 2, p. 42, pl. 5, figs. 7, 8. Recent, eastern coast of the U. S.

Bandy, 1954, U. S. Geol. Survey Prof. Paper 254-F, pl. 29, fig. 4. Recent, Gulf of Mexico.

Nodobaculariella mexicana (Cushman), 1922, Carnegie Inst. Washington Pub. 311, p. 70, pl. 11, figs. 7, 8. Recent, Tortugas Islands.

This paper, pl. 29, fig. 7 .

This species was originally described under Articulina; however, it lacks the miliolid chamber arrangement in the early part, the chambers being in one plane throughout, and it is placed, therefore, in the genus Nodobaculariella Cushman.

Nonion affinis (Reuss). 1851, Deutsche Geol. Gesell., Zeitschr., Berlin, Band 3, p. 72, pl. 5, fig. 32. Oligocene, Germany.

Bandy, 1953, Jour. Paleontology, v. 27, no. 2, p. 177, pl. 21, fig. 8 (given incorrectly as $N$. barleeanus). Recent, off Point Conception, Calif.

This paper, pl. 30 , fig. 17.

Nonionella atlantica Cushman, 1947, Cushman Lab. Foram. Research Contr., v. 23, pt. 4, p. 90, pl. 20, figs. 4, 5 . Recent, Florida.

Bandy, 1954, U. S. Geol. Survey Prof. Paper 254-F, pl. 29, fig. 10. Recent, Gulf of Mexico.

Nonionella grateloupi (D'Orbigny), 1826, Annales sci. nat., v. 7, p. 294, no. 19; in Ramon de la Sagra, Histoire physique, politique et naturelle de l'Ile de Cuba, 1839, p. 46, pl. 6, figs. 6-7. Recent, Cuba and Jamaica.

Cushman, 1939, U. S. Geol. Survey Prof. Paper 191, p. 21, pl. 6, figs. 1-7.

Orbulina universa D'Orbigny, 1839, in Ramon de la Sagra, Histoire physique, politique et naturelle de l'Ile de Cuba, p. 3 , pl. 1, fig. 1. Recent, Cuba and Jamaica.

Pavonina atlantica Cushman, 1922, U. S. Natl. Mus. Bull. 104, pt. 3, p. 51, pl. 19, fig. 1. Recent, Florida and West Indies.

Phleger and Parker, 1951, Geol. Soc. America Mem. 46, pt. 2, p. 17, pl. 8, figs. 6, 7. Recent, Gulf of Mexico.

Peneroplis proteus D'Orbigny, 1839, in Ramon de la Sagra, Histoire physique, politique et naturelle de l'Ile de Cuba, p. 60, pl. 7, figs. 7-11. Recent, Cuba and Jamaica.

Cushman, 1930, U. S. Natl. Mus. Bull. 104, pt. 7, p. 37, pl. 13, figs. 1-17. Recent, western Atlantic.

Planorbulina mediterranensis D'Orbigny, 1826, Annales sci. nat., v. 7, p. 280, no. 2, pl. 14, figs. 4-6; Modèles, no. 79 .

Bandy, 1954, U. S. Geol. Survey Prof. Paper 254-F, pl. 31, fig. 3. Recent, Gulf of Mexico.

Planulina foveolata (H. B. Brady), 1884, Challenger Rept., Zoology, v. 9, p. 674, pl. 94, fig. 1. Recent, near Bermuda.

Phleger and Parker, 1951, Geol. Soc. America Mem. 46, pt. 2, p. 33, pl. 18, figs. 9, 10. Recent, Gulf of Mexico. 
The figure of the type appears to represent a specimen that is much thicker than the average; however, specimens compared with the type and paratypes are reported to be the same species.

Planulina ornata (D'Orbigny), 1839, Voyage dans l'Amérique méridionale, v. 5, pt. 5, Foraminifères, p. 40, pl. 6 , figs. 7-9. Recent, off the coast of Chile.

Bandy, 1953, Jour. Paleontology, v. 27, no. 2, p. 177, pl. 24, fig. 4. Recent, off the coast of California.

Bandy, 1954, U. S. Geol. Survey Prof. Paper 254-F, pl. 31, fig. 2. Recent, Gulf of Mexico.

Young specimens have a truncate edge, whereas adults tend to develop a sharp edge. $P$. exorna Phleger and Parker (1951) is considered to be a junior synonym of $P$. ornata by this author.

Polymorphina pulchella (D'Orbigny), 1839, in Ramon de la Sagra, Histoire physique, politique et naturelle de l'Hle de Cuba, p. 129, pl. 2, figs. 4-6. Recent, Cuba and Martinique.

Cushman, 1922, Carnegie Inst. Washington Pub. 311, p. 33, pl. 4, figs. 7, 8. Recent, Tortugas region.

Poroeponides cribrorepandus Asano and Uchio, 1951, in Stach, Illustrated catalogue of Japanese Tertiary smaller Foraminifera, pt. 14, Rotaliidae, p. 18, tfs. 134, 135. Pliocene, Japan.

Bandy, 1954, U. S. Geol. Survey Prof. Paper 254-F, pl. 30, fig. 3. Recent, Gulf of Mexico.

This species is commonly identified as Eponides repandus (Fichtel and Moll); however, the pores on the apertural face are distinctive of the genus Poroeponides. The type figure of Eponides (E. repandus) does not exhibit this character.

Proteonina atlantica Cushman, 1944, Cushman Lab. Foram. Research Special Pub. 12, p. 5, pl. 1, fig. 4. Recent, off the New England coast.

Bandy, 1954, U. S. Geol. Survey Prof. Paper 254-F, pl. 28, fig. 1. Recent, Gulf of Mexico.

Pseudoclavulina constans Bandy, n. sp., this paper, p. 198, pl. 30, fig. 5 .

Pullenia quinqueloba (Reuss), 1851, Deutsche geol. Gesell. Zeitschr., Band 3, p. 71, pl. 5, fig. 31. Oligocene, Germany.

Phleger and Parker, 1951, Geol. Soc. America Mem. 46, pt. 2, p. 29, pl. 15, figs. 12, 13 . Recert, Gulf of Mexico.

Pulleniatina obliquiloculala (Parker and Jones), 1865, Philos. Trans., v. 155 , p. 368, pl. 19, fig. 4.

Phleger and Parker, 1951, Geol. Soc. America Mem. 46, pt. 2, p. 35, pl. 19, figs. 19, 20 . Recent, Gulf of Mexico.

Pyrgo comata (Brady), 1881, Quart. Jour. Micros. Soc., v. 21, p. 45.

Brady, 1884, Challenger Rept., Zoology, v. 9, p. 144, pl. 3, fig. 9. Recent, cosmopolitan.

Bandy, 1954, U. S. Geol. Survey Prof. Paper 254-F, pl. 28, fig. 9. Recent, Gulf of Mexico.

Pyrgo nasuta Cushman, 1935, Smithsonian Misc. Coll., v. 91, no. 21 , p. 7 , pl. 3 , figs. 1-4.

Phleger and Parker, 1951, Geol. Soc. America Mem. 46, pt. 2, p. 7, pl. 3, figs. 12-14. Recent, Gulf of Mexico.

Pyrgo peruviana (D'Orbigny), 1839, Voyage dans l'Amerique méridionale, v. 5 , pt. 5 , Foraminifères, p. 65 , pl. 9 , figs. 1-3. Recent, off Peru.

Quinqueloculina agglutinans D'Orbigny, 1839, in Ramon de la Sagra, Histoire physique, politique et naturelle de l'Ile de Cuba, p. 195, pl. 12, figs. 11-13. Recent, Cuba and Jamaica.
Many subsequent figures of this species do not show the square cross section of the chambers which is quite characteristic of this species.

Quinqueloculina akneriana D'Orbigny, 1846, Foram. Fossiles Vienne, p. 290, pl. 18, figs. 16-21. Middle Miocene, Vienna.

Quinqueloculina bicostata D'Orbigny, 1839, idern., p. 195, pl. 12, figs. 8-10. Recent, Cuba and Jamaica.

Phleger and Parker, 1951, Geol. Soc. America Mem. 46, pt. 2, p. 7, pl. 3, fig. 15. Recent, Gulf of Mexico.

Quinqueloculina bosciana D'Orbigny, 1839, in Ramon de la Sagra, Histoire physique, politique et naturelle de l'Ile de Cuba, p. 191, pl. 11, figs. 22-24, Recent, Cuba and Jamaica.

This paper, pl. 29, fig. 4.

Quinqueloculina compta Cushman, 1947, Cushman Lab. Foram. Research Contr., v. 23, pt. 4, p. 87, pl. 19, fig. 2. Recent, off coast of Florida.

Bandy, 1954, U. S. Geol. Survey Prof. Paper, 254-F, pl. 28, fig. 2. Recent, Gulf of Mexico.

This paper, pl. 29, fig. 5 .

Quinqueloculina dutemplei D'Orbigny, 1846, Foram. Fossiles Vienna, p. 294, pl. 19, figs. 10-12. Middle Miocene, Vienna.

This paper, pl. 29, fig. 9 .

Quinqueloculina horrida Cushman, 1947, Cushman Lab. Foram. Research Contr., v. 23, p. 88, pl. 19, fig. 1. Recent, coastal waters of South Carolina.

Phleger and Parker, 1951, Geol. Soc. America Mem: 46, pt. 2, p. 7, pl. 3, figs. 18, 19 . Recent, Gulf of Mexico.

Quinqueloculina jugosa Cushman, 1944, Cushman Lab. Foram. Research, Special Pub. 12, p. 13, fig. 15. Recent, off Massachusetts.

This paper, pl. 29 , fig. 8.

Quinqueloculina lamarckiana D'Orbigny, 1839, in Ramon de la Sagra, Histoire physique, politique et naturelle de l'Ile de Cuba, p. 189, pl. 11, figs. 14, 15. Recent, Cuba and Jamaica.

Bandy, 1954, U. S. Geol. Survey Prof. Paper 254-F, pl. 28, fig. 3. Recent, Gulf of Mexico.

Quinqueloculina poeyana D'Orbigny, 1839, in Ramon de la Sagra, Histoire physique, politique et naturelle de l'Ile de Cuba, p. 191, pl. 11, figs. 25-27. Recent, Cuba and Jamaica.

This paper, pl. 29, fig. 6 .

Quinqueloculina polygona D'Orbigny, 1839, in Ramon de la Sagra, Histoire physique, politique et naturelle de II'le de Cuba, p. 198, pl. 12, figs. 21-23. Recent, Cuba and Jamaica.

Cushman, 1929, U. S. Natl. Mus. Bull. 104, pt. 6, p. 28, pl. 3, fig. 5. Recent, West Indies.

Quinqueloculina rhodiensis Parker, 1953, Cushman Foundation Foram. Research Special Pub. 2, p. 12, pl. 2, figs. 15-17. Recent, Gulf of Mexico.

This species is recorded by many authors as $Q$. costata D'Orbigny, a homonym, and Parker corrected the name in the cited reference.

This paper, pl. 29, fig. 10 .

Raphanulina tuberculata (D'Orbigny), 1846, Foram. Fossil Vienne, p. 230, pl. 13, figs. 21, 22. Middle Miocene, Vienna.

Bandy, 1949, Bull. Am. Paleontology, v. 32, no. 131, p. 70, pl. 10, fig. 6. Eocene, Alabama.

Rectobolivina advena (Cushman), 1922, Carnegie Inst. Washington Pub. 311 (v. 17), p. 35, pl. 5, fig. 2. Recent, Tortugas region. 
Bandy, 1954, U. S. Geol. Survey Prof. Paper 254-F, pl. 31 , fig. 8. Recent, Gulf of Mexico.

Reophax scorpiurus Montfort, 1808, Conchylologie Systematique

- v. 1, p. 331, fig. p. 330 . Recent, Adriatic.

Phleger and Parker, 1951, Geol. Soc. America Mem. 46, pt. 2, p. 3, pl. 1, figs. 7, 8. Recent, Gulf of Mexico.

Reussella atlantica Cushman, 1947, Cushman Lab. Foram. Research Contr. v. 23, pt. 4, p. 91, pl. 20, figs. 6, 7 . Recent, off southeastern coast of the U.S.

Bandy, 1954, U. S. Geol. Survey Prof. Paper 254-F, pl. 31, fig. 7. Recent, Gulf of Mexico.

Robulus calcar (Linne), Systematique Naturae, ed. 10, 1758, v. 1, p. 708 .

Cushman, 1923, U. S. Natl. Mus. Bull. 104, pt. 4, p. 115 , pl. 30, fig. 7, pl. 31, figs. 4, 5. Recent, western Atlantic, Caribbean, and Gulf of Mexico.

This paper, pl. 30, fig. 11 .

Robulus stephensoni Cushman, 1939, Cushman Lab. Foram. Research Contr., v. 15, p. 90, pl. 16, figs. 2, 3. Upper Cretaceous, Tennessee.

This species was very rare and it is almost exactly like the types of this species from the Cretaceous. Perhaps the specimens of this investigation are reworked from Cretaceous bottom outcrops.

Robulus suborbicularis Parr, 1950, British Australian, New Zealand, Antarctic Research Exped., Rept., series B (Zoology and Botany), v. 5, pt. 6, p. 321, pl. 11, figs. 5, 6. Recent, Tasmania.

This paper, pl. 30, fig. 12 .

Rotorbinella basilica Bandy, n. sp., this paper, p. 199,pl. 31, fig. 3. Saracenaria ampla Cushman and Todd, 1945, Cushman Lab.

Foram. Research Special Pub. 15, p. 31, pl. 5, figs. 5-6. Miocene, Jamaica.

Schenckiella occidentalis (Cushman), 1922, U. S. Natl. Mus. Bull. 104, pt. 3, p. 87, pl. 17, figs. 1, 2. Recent, Gulf of Mexico.

Phleger and Parker, 1951, Geol. Soc. America Mem. 46, pt. 2, p. 6, pl. 3, figs. 5-7. Recent, Gulf of Mexico.

Sigmoilina subpoeyana (Cushman), 1922, Carnegie Inst. Washington Pub. 311, p. 66; U. S. Natl. Mus. Bull. 104, pt. 6, p. 31, pl. 5, fig. 3. Recent, West Indies.

Bandy, 1954, U. S. Geol. Survey Prof. Paper 254-F, pl. 29, fig. 1. Recent, Gulf of Mexico.

This paper, pl. 29, fig. 1 .

This species was originally described as Quinqueloculina, and many authors have confused it also with Spiroloculina antillarum D'Orbigny.

Sigmoilina tenuis (Czjzek), 1848, Haidinger's Naturwiss. Abh., v. 2, p. 149, pl. 13, figs. 31-34. Miocene, Austria.

Phleger and Parker, 1951, Geol. Soc. America Mem. 46, pt. 2, p. 8, pl. 4, fig. 7. Recent, Gulf of Mexico.

Siphonina bradyana Cushman, 1927, U. S. Natl. Mus. Proc., v. 72, art. 20, p. 11, pl. 1, fig. 4. Recent, West Indies.

Phleger and Parker, 1951, Geol. Soc. America Mem. 46, pt. 2, p. 24, pl. 12, figs. 13, 14 . Recent, Gulf of Mexico.

Siphotextularia olianaensis Colom and Ruiz de Gaona, 1950, Spain Inst. Inv. Geol. "Lucas Mallada," Estud. Geol., v. 6, no. 12 , p. 413 , fig. p. 415 , tf. 16 . Eocene, Spain.

This paper, pl. 30 , fig. 9 .

Sorites orbitolitoides (Hofker), 1930, Siboga Report II, p. 149, pl. 55, figs. $8,10,11$; pl. 37 , figs. 4,6 ; pl. 58, figs. 1-5; pl. 61, figs. 3, 14. Recent, Florida, South Carolina, and Netherlands Indies.

Bandy, 1954, U. S. Geol. Survey Prof. Paper 254-F, pl. 29, fig. 5. Recent, Gulf of Mexico.
Sphaeroidina bulloides D'Orbigny, 1826, Annales sci. nat., v. 7, p. 267, no. 1, Modèles, no. 65 .

Gushman, 1924, U. S. Natl. Mus. Bull. 104, pt. 5, p. 36, pl. 7, figs. 1-6. Recent, northeastern coast of U. S.

Spiroloculina depressa D'Orbigny, 1826, Annales sci. nat., ser. 1, tome 7, p. 298; Modèles, no. 92.

Cushman and Todd, 1944, Cushman Lab. Foram. Research Special Pub. 11, p. 28, pl. 1, figs. 1, 6; pl. 5, figs. 1-9.

This paper, pl. 29, fig. 2.

Spiroplectammina floridana (Cushman), 1922, Carnegie Inst. Washington Pub. 311, v. 17, p. 24, pl. 1, fig. 7. Recent, Tortugas region.

Phleger and Parker, 1951, Geol. Soc. America Mem. 46, pt. 2, p. 4, pl. 1, figs. 25, 26. Recent, Gulf of Mexico.

Stomatorbina concentrica (Parker and Jones), 1864, Trans. Linnean Soc. Zool., v. 24, p. 470, pl. 48, fig. 14. Recent.

Phleger and Parker, 1951, Geol. Soc. America Mem. 46, pt. 2, p. 22, pl. 12, fig. 2. Recent, Gulf of Mexico.

Streblus sobrinus (Shupack), 1934, Am. Mus. Novitates, no. 737, p. 6, fig. 4. Pleistocene and Recent, New York Harbor.

Bandy, 1954, U. S. Geol. Survey Prof. Paper 254-F, pl. 30, fig. 7. Recent, Gulf of Mexico.

Streblus tepidus (Cushman), 1926, Carnegie Inst. Washington Pub. 344, p. 79, pl. 1. Recent, Puerto Rico.

This paper, pl. 31, fig. 2.

Textularia candeiana D'Orbigny, 1839, in Ramon de la Sagra, Histoire physique, politique et naturelle de l'Ile de Cuba, p. 143, pl. 1, figs. 25-27. Recent, Cuba and Jamaica.

Bandy, 1954, U. S. Geol. Survey Prof. Paper 254-F, pl. 29, fig. 2. Recent, Gulf of Mexico.

Textularia conica D'Orbigny, 1839, in Ramon de la Sagra, Histoire physique, politique et naturelle de l'lle de Cuba, p. 143, pl. 1, figs. 19, 20 . Recent, Cuba and Jamaica.

This paper, pl. 30, fig. 6 .

Textularia foliacea Heron-Allen and Earland var. occidentalis Cushman, 1922, U. S. Natl. Mus. Bull. 104, pt. 3, p. 16, pl. 2, fig. 13. Recent, Cuba.

This paper, pl. 30, fig. 10.

Textularia mayori Cushman, 1922, Carnegie Inst. Washington Pub. 311, v. 17, p. 23, pl. 2, fig. 3. Recent, Tortugas region.

Bandy, 1954, U. S. Geol. Survey Prof. Paper 254-F, pl. 29, fig. 3. Recent, Gulf of Mexico.

Textularia pseudotrochus Cushman, 1922, U. S. Natl. Mus. Bull. 104, pt. 3, p. 21, pl. 5, figs. 1-3. Recent, off southern coast of Florida.

This paper, pl. 30, fig. 7 .

Textularia secasensis Cushman and McCulloch, 1940, Allan Hancock Pacific Exped. Pub., v. 6, no. 2, p. 141, pl. 16, fig. 24. Recent, eastern Pacific.

Textulariella barrettii (Jones and Parker), 1876, Soc. Malacologique de Belgique, Annales (Mem.), tome 11 (ser. 2, tome 1), p. 99, fig. p. 99 . Tertiary and Recent, West Indies.

Cushman, 1922, U. S. Natl. Mus. Bull. 104, pt. 3, p. 20, pl. 3, figs. 3-6. Recent, Key West and West Indies.

Triloculina affinis D'Orbigny, 1852, Prodrome de Paleontologie stratigraphique univ. des animaux mollusques et rayonnes, v. 3 , p. 161 .

Cushman, 1932, U. S. Natl. Mus. Bull. 161, pt. 1, p. 58-59 pl. 13, fig. 4. Recent, tropical Pacific.

The angular character of the edges serves to distinguish this species, although in many cases the two species have probably been included under $T$. trigonula. 
Triloculina bellatula Bandy, n. sp., this paper p. 198, pl. 29, fig. 11. Probably Miliammina fusca (H. B. Brady) has been included with the frequency counts of this species; however, most of the specimens were calcareous with a bifid tooth and belong under this new species.

Triloculina linneiana D'Orbigny var. comis Bandy, n. var., this paper, p. 198, pl. 29, fig. 12.

Triloculina trigonula (Lamarck), 1807, Annales Nat. Hist. Paris Mus., v. 5, p. 351, no. 3, tome 9, pl. 17, fig. 4.

Bandy, 1954, U. S. Geol. Survey Prof. Paper 254-F, pl. 28, fig. 5. Recent, Gulf of Mexico.

Trochammina laevigata Cushman and Bronniman, 1948, Contr. Cushman Lab. Foram. Research, v. 24, pt. 2, p. 41, pl. 7, figs. 21, 22. Recent, Mangrove swamp, Trinidad.

This paper, pl. 29, fig. 13.

Trochammina simplissima Cushman and McCulloch, 1948, Cushman Lab. Foram. Research Contr., v. 24, p. 76. New name for $T$. pacifica var. simplex. Recent, off Lower California.

This paper, pl. 29, fig. 14 .

Uvigerina bellula Bandy, new, name, this paper, p. 199, pl. 31, fig 13. Uvigerina fintii Cushman, 1923, U. S. Natl. Mus. Bull. 104, pt. 4 , p. 165 , pl. 42 , fig. 13 . Recent, West Indies.

Phleger and Parker, 1951, Geol. Soc. America Mem. 46, pt. 2, p. 18, pl. 8, figs. 15, 16 . Recent, Gulf of Mexico.

Uvigerina hispido-costata Cushman and Todd, 1945, Cushman Lab. Foram. Research Special Pub. 15, p. 51, pl. 7, figs. 27, 31. Miocene, Jamaica.

Phleger and Parker, 1951, Geol. Soc. America Mem. 46, pt. 2, p. 18, pl. 8, figs. 17-21, 23. Recent, Gulf of Mexico.

This paper, pl. 31, fig. 14 .

Valvulineria sp. One or two specimens of this genus were found and seem to be undescribed. Because of the lack of specimens and its lack of importance in this study, no attempt was made to establish a new species at this time.

Virgulina schreibersiana Czjzek, Haidinger's Naturwiss. Abb., Band 2, p. 11, pl. 13, figs. 18-21. Miocene, Vienna Basin.

Bandy, 1954, U. S. Geol. Survey Prof. Paper 254-F, p. 139, pl. 31, fig. 10. Recent, Gulf of Mexico.

\section{SYSTEMATIC PALEONTOLOGY}

Ecologic studies of Foraminifera in the eastern Gulf of Mexico off the coast of Florida and Alabama reveal 3 new species, 1 new variety, and 1 homonym. These five are figured and described herein in order to make the names available for the ecologic studies.

The types are catalogued and deposited in the U. S. National Museum, Washington, D. C. The classification used is that of Galloway (1933).

\section{Family ATAXOPHRAGMIDAE Schwager, 1877 Genus PSEUdOCLAvULINA Cushman, 1936 Pseudoclavulina constans Bandy, n. sp. Plate 30, figure 5.}

1951. Pseudoclavulina mexicana Phleger and Parker (not Cushman), Geol. Soc. America Mem. 46, pt. 2, pl. 2, figs. 15, 16.

Test of moderate size for the genus, averaging about $1 \mathrm{~mm}$ in length; early triserial portion roughly trihedral with closely appressed chambers, later uniserial part with from 3 to 5 closely appressed chambers which are shorter than they are'broad at first and then become about as long as they are broad near the apertural end; sutures slightly depressed in the uniserial portion, flush with the surface in the triserial portion; wall fairly roughly finished, of calcareous grains for the most part; aperture terminal, rounded to ovate with a very short neck. Length, $1.00 \mathrm{~mm}$; breadth, $0.30 \mathrm{~mm}$.

This species differs from Pseudoclavulina mexicana (Cushman) (1922b, p. 83, pl. 16, figs. 1-3) in that the chambers are much more closely appressed in the uniserial portion, the aperture is at the end of a short tubular neck, whereas there is a much coarser and conically shaped neck in $P$. mexicana, and also the early trihedral portion is much smaller and much less distinctly trihedral than in Cushman's species.

Holotype (USNM 624349) from station 2168, 6.2 fathoms, off the west coast of Florida, lat. $26^{\circ} 08.6^{\prime} \mathrm{N}$., long. $83^{\circ} 54.2^{\prime} \mathrm{W}$.

\section{Family MILIOLIDAE D'Orbigny, 1839 Genus TRILOCULINA D'Orbigny, 1826 Triloculina bellatula Bandy, n. sp. Plate 29, figure 11.}

Test elongate in side view, breadth about three-fifths the length; edges rounded in apertural view; chambers distinct; wall calcareous with arenaceous coating; apertural end does not project beyond test; aperture circular with small bifid tooth. Length, $0.55 \mathrm{~mm}$; breadth, $0.30 \mathrm{~mm}$; thickness, $0.20 \mathrm{~mm}$.

This species is rare and is quite distinctive in its small size, in that the aperture does not project, and in the presence of the small bifid tooth. Triloculina tortuosa Cushman (1921b) is larger and has a long neck without a tooth.

Holotype (USNM 624397) from station 442, 28 feet, off the west coast of Florida, lat. $27^{\circ} 36.65^{\prime} \mathrm{N}$., long. $82^{\circ} 39.32^{\prime} \mathrm{W}$.

\section{Triloculina linneiana D'Orbigny var. comis Bandy, n. var. \\ Plate 29, figure 12}

Test elongate ovate in side view, breadth about onehalf the length; edges round in apertural view; chambers distinct, rounded in cross section; wall ornamented with moderately heavy longitudinal costae, about 20 to 30 on the last chamber; apertural end projecting, and flaring slightly; aperture rounded with prominent bifid tooth which usually projects slightly. Length, 1.60 $\mathrm{mm}$; breadth, $0.80 \mathrm{~mm}$; thickness, $0.60 \mathrm{~mm}$.

This variety is similar in general to $T$. linneiana D'Orbigny (1839, p. 172). It differs from D'Orbigny's species in possessing more costae which are not as strongly developed and in being much larger. This new variety differs from $T$. linneiana var. caloosahat- 
cheensis Cole (1931, p. 25) in having a long flaring aperture with a prominent bifid tooth and the costae are not as prominent.

Holotype (USNM 624398) from station 1214, 42 feet, off the west coast of Florida, lat. $27^{\circ} 29.6^{\prime} \mathrm{N}$., long. $82^{\circ} 54.0^{\prime} \mathrm{W}$.

\section{Family ROTALIIDAE Reuss, 1860 Genus ROTORBINELLA Bandy, 1944 \\ Rotorbinella basilica Bandy, n. sp.}

Plate 31, figure 3

Test biconvex, dorsal side sometimes more convex and sometimes less convex than the ventral side; edge angled, may be abruptly rounded in the latter part of the final whorl; about 6 to 8 chambers in the final whorl, enlarging fairly rapidly as added; inner ends of chambers with translucent thickening on ventral side; dorsal spire with no secondary thickening, showing about 12 chambers in all comprising the whorl and one-half that make up the test; dorsal sutures curved, oblique, and slightly depressed, especially in the later part of the test; ventral sutures only slightly curved and oblique, much depressed, especially in the later part of the test; wall with medium-sized perforations; umbilicus with a fairly large distinct single boss; aperture a low arched opening extending from near the edge into the umbilicus with an upper lip. Diameter, $0.25 \mathrm{~mm}$; thickness, $0.11 \mathrm{~mm}$.

The species differs from Rotorbinella versiformis (Bandy) (1953, p. 179) in lacking the dorsal thickening of that species, in being nearly biconvex, and in that the test is made up of only about $1 \frac{1}{2}$ whorls. Rotorbinella bassleri (Cushman and Cahill) (1933, p. 32) differs in that it possesses several whorls, it is nearly planoconvex, it possesses distinct sutural reentrants, and it is larger. Rotorbinella translucens (Phleger and Parker) (1951, p. 24) differs also in possessing several whorls and in having a small or poorly defined umbilical plug.

Holotype (USNM 624375) from station 1425, 23 fathoms, off the west coast of Florida, lat. $26^{\circ} 17.2^{\prime} \mathrm{N}$., long. $84^{\circ} 03.3^{\prime} \mathrm{W}$.

\section{Family UVIGERINIDAE Galloway and Wissler, 1927 Genus Uvigerina D'Orbigny, 1826 \\ Uvigerina bellula Bandy, new name}

Plate 31, figure 13

1896. Uvigerina auberiana D'Orbigny var. laevis Goës, Bull. Mus. Comp. Zool., v. 29, p. 51, pl. 4, figs. 71-74, 1896. (This variety is a homonym of $U$. laevis Ehrenberg, 1845, K. Preuss Akad. Wiss. Berlin, p. 377, 317.)

Test small, elongate fusiform, greatest width about the middle; periphery lobulate; chambers inflated, three to a whorl in the early portion, assuming a very loose triserial arrangement in the later part; early chambers about as high as wide, later ones becoming higher than wide; wall finely perforate and smooth excepting for a slight tendency to become hispid in the early part of the test; aperture terminal, round, with a prominent neck and lip. Length, $0.40 \mathrm{~mm}$; diameter, $0.10 \mathrm{~mm}$.

This species is well known, and its presence in the Gulf of Mexico has been reported by Phleger and Parker (1951, p. 18). Ehrenberg's U. laevis has priority, and so this species of Goës is renamed herein.

Hypotype (USNM 624402) from station 2166, 69 fathoms, off the west coast of Florida, lat. $26^{\circ} 07.4^{\prime} \mathrm{N}$., long. $83^{\circ} 57.7^{\prime} \mathrm{W}$.

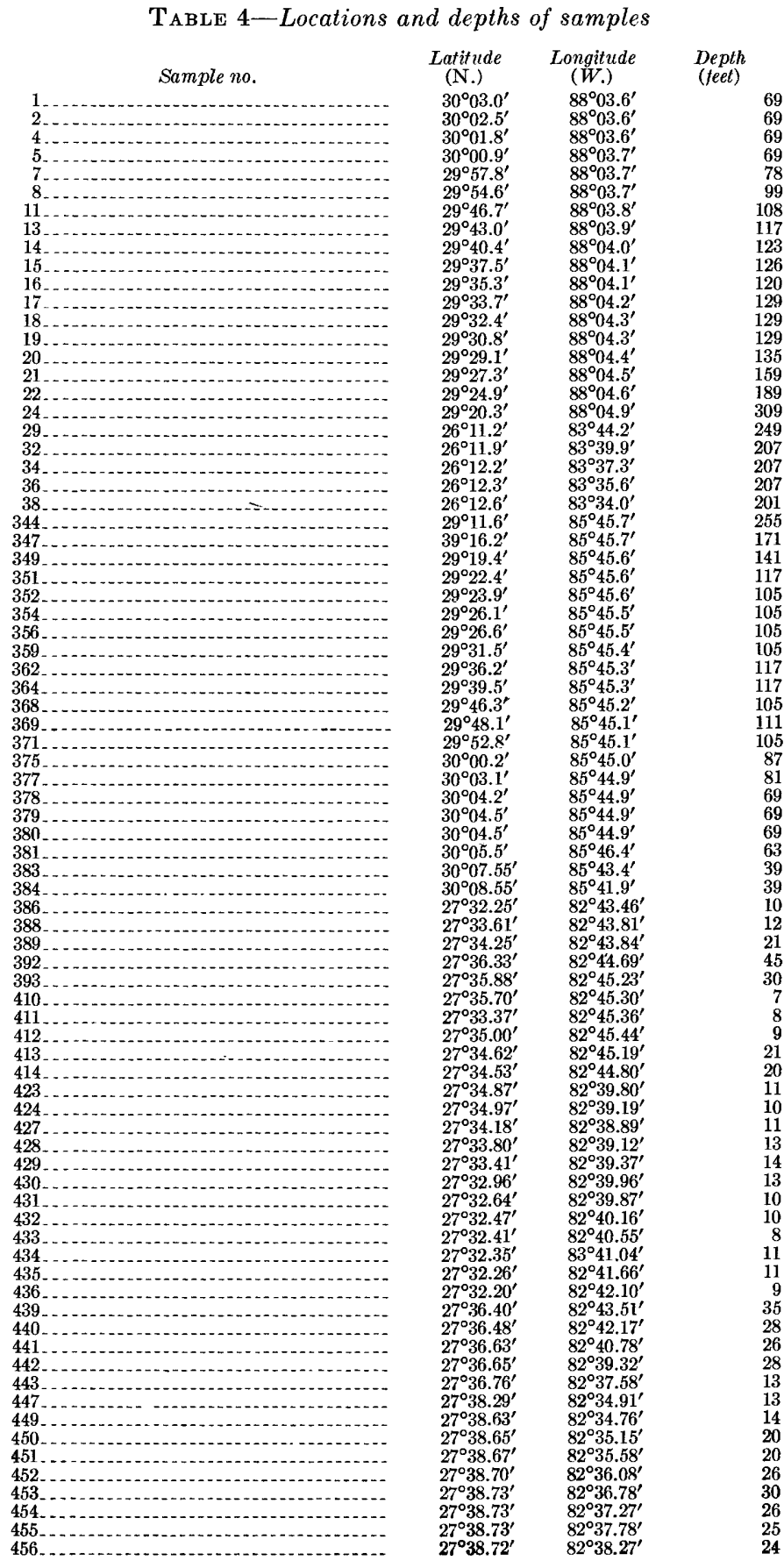


TABLE 4-Locations and depths of samples-Continued

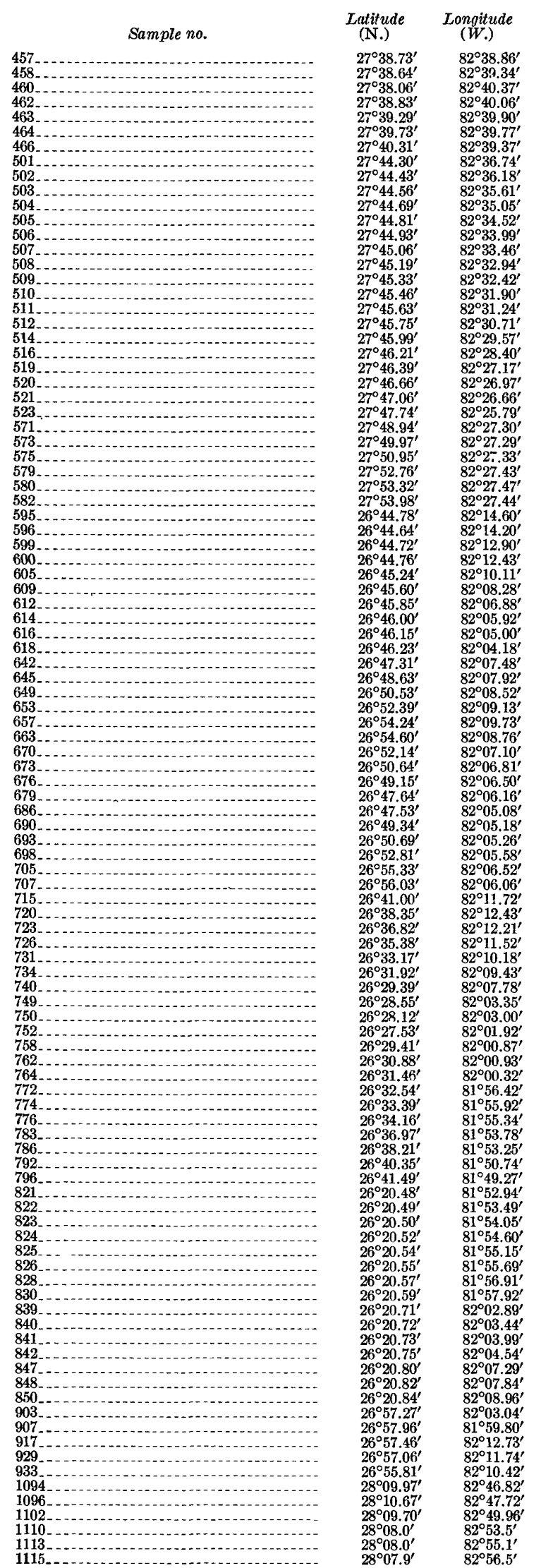

TABLE 4-Locations and depths of samples-Continued

Depth
(feet)

Sample no.

$\begin{array}{ccc}\text { Latitude } & \text { Longitude } & \text { Depth } \\ (N .) & (W .) & \text { (feet) }\end{array}$

$\begin{array}{ll}28^{\circ} 07.9^{\prime} & 82^{\circ} 57.0^{\prime} \\ 28^{\circ} 07.9^{\prime} & 82^{\circ} 57.6^{\prime} \\ 28^{\circ} 07.8^{\prime} & 82^{\circ} 58.7^{\prime}\end{array}$

$28^{\circ} 07.9$

$28^{\circ} 07.8^{\prime}$

$28^{\circ} 07.8^{\prime}$
$28^{\circ} 07.8^{\prime}$

$28^{\circ} 07.8^{\circ}$

$28^{\circ} 07.6^{\prime}$

$28^{\circ} 07.6^{\prime}$

$28^{\circ} 07.6^{\prime}$

$28^{\circ} 07.5^{\circ}$

$28^{\circ} 07.6^{\prime}$

$28^{\circ} 07.6^{\prime}$
$28^{\circ} 07.7^{\prime}$

$28^{\circ} 07.8^{\prime}$
$28^{\circ} 07.8^{\prime}$

$28^{\circ} 07.8^{\prime}$
$28^{0} 07.9^{\prime}$

$28^{\circ} 07.9^{\prime}$
$28^{\circ} 08.0^{\prime}$

$28^{\circ} 08.0^{\prime}$

$28^{\circ} 08.0^{\prime}$

$28^{\circ} 08.2^{\prime}$

$28^{\circ} 08.8^{\prime}$

$28^{\circ} 08.8^{\prime}$
$28^{\circ} 09^{\prime} .0^{\prime}$

$28^{\circ} 09.0$

$28^{\circ} 09.7^{\prime}$

$28^{\circ} 09.9^{\prime}$

$28^{\circ} 09.8^{\prime}$
$28^{\circ} 09.6^{\prime}$

$28^{\circ} 09.5$

$28^{\circ} 09.3^{\prime}$

$28^{\circ} 08.9^{\prime}$
$28^{\circ} 08.7^{\prime}$

$28^{\circ} 08.7^{\prime}$
$28^{\circ} 08.5^{\prime}$

$28^{\circ} 8.2^{2}$

$28^{\circ} 98.0^{\prime}$
$28^{\circ} 07.8^{\prime}$

$28^{\circ} 07.8^{\prime}$
$28^{\circ} 08.1^{\prime}$

$28^{\circ} 08.4^{\prime}$
$28^{\circ} 08.7^{\prime}$

$28^{\circ} 08.9^{\prime}$

$28^{\circ} 09$.

$28^{\circ} 08.8^{\prime}$

$28^{\circ} 09.4^{\prime}$

$28^{\circ} 10.0^{\prime}$

$28^{\circ} 10.8^{\prime}$

$28^{\circ} 11.2^{\prime}$

$28^{\circ} 11.0^{\prime}$

$28^{\circ} 11.6^{\prime}$

$27^{\circ} 37.5^{\circ}$

$27^{\circ} 35.0^{\prime}$

$27^{\circ} 31.0^{\prime}$

$27^{\circ} 28.1^{\prime}$
$27^{\circ} 26.6^{\prime}$

$27^{\circ} 26.6^{\circ}$
$27^{\circ} 24.9^{\prime}$

$27^{\circ} 22.2^{\prime}$

$27^{\circ} 11.0^{\prime}$

$27^{\circ} 19.8^{\prime}$

$27^{\circ} 19.7^{\prime}$
$27^{\circ} 11.7^{\prime}$

$27^{\circ} 19.7^{\circ}$

$27^{\circ} 19.5$

$27^{\circ} 19.5^{\prime}$

$27^{\circ} 19.3^{\prime}$

$27^{\circ} 19.1^{\circ}$

$27^{\circ} 19.2^{\prime}$

$27^{\circ} 19.2^{\prime}$
$27^{\circ} 19.2^{\prime}$
$27^{\circ} 18.9^{\prime}$

$82^{\circ} 59.0^{\prime}$

$83^{\circ} 01.8^{\prime}$

$3^{\circ} 04.3^{\prime}$

${ }^{83^{\circ} 05.7^{\prime}}$

$83^{\circ} 07.4^{\prime}$

$83^{\circ} 07.9^{\prime}$

$83^{\circ} 11.1^{\prime}$

$83^{\circ} 12.8^{\prime}$

$3^{\circ} 13.6^{\prime}$

$83^{\circ} 15.9^{\prime}$

$83^{\circ} 17.1^{\circ}$

$3^{\circ} 18.9$

$83^{\circ} 20.8^{\prime}$

$83^{\circ} 22.8^{\prime}$

$83^{\circ} 24.9^{\prime}$

${ }_{83^{\circ} 30.7^{\prime}}^{83^{\circ}}$

$83^{\circ} 32.7$

$83^{\circ} 34.4^{\prime}$

$83^{\circ} 37.8^{\prime}$

$83^{\circ} 42.0^{\prime}$
$83^{\circ} 441^{\prime}$

$83^{\circ} 44.1^{\prime}$
$83^{\circ} 46.2^{\prime}$

$83^{\circ} 48.6^{\prime}$

$83^{\circ} 50 . .^{\prime}$

$83^{\circ} 55.7^{\prime}$ 
TABLE 4-Locations and depths of samples-Continued

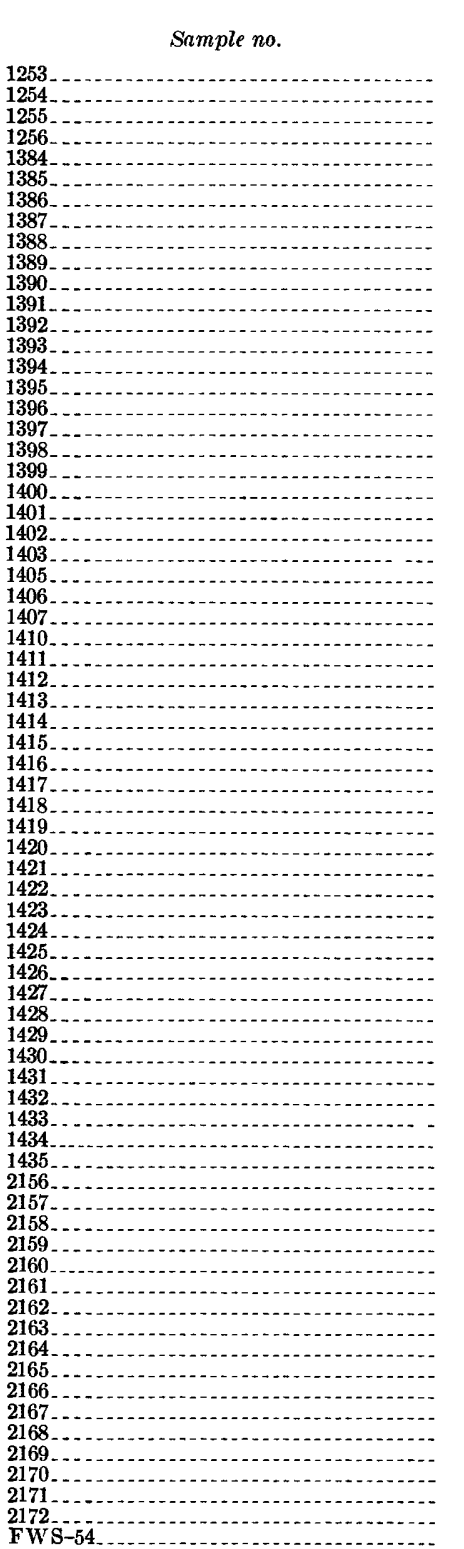

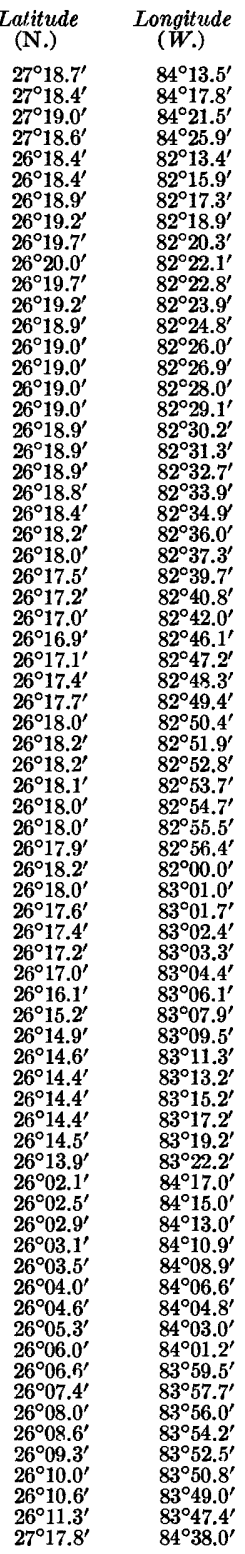
Depth
(feet)

\section{LITERATURE CITED}

Acosta, J. T., 1940, Algunos Foraminiferos nuevos de las costas Cubanas: Torreia, Mus. Poey, Universidad de la Habana, Cuba, no. 5, p. 3-6.

Andersen, H. V., 1952, Buccella, a new genus of the rotalid Foraminifera: Wash. Acad. Sci. Jour., v. 42, no. 5, p. 143-151.

Asano, Kiyoshi, 1944, Hanzawaia, a new genus of Foraminifera from the Pliocene of Japan: Geol. Soc. Japan Jour., Tokyo, v. 51, no. 606, p. 97,98 .

Bandy, O. L., 1949, Eocene and Oligocene Foraminifera from Little Stave Creek, Clarke County, Ala.: Bull. Paleontology, v. 32 , no. 131,210 p.

1951, Bathymetric distribution of some shallow-water Foraminifera in the Gulf of Mexico [abs.]: Geol. Soc. America Bull., v. 62 , no. 12 , pt. 2, p. 1521.
1953, Ecology and paleoecology of some California Foraminifera; Part 1, The frequency distribution of Recent Foraminifera off California: Jour. Paleontology, v. 27, no. 2, p. 161-182.

p. 1954, Distribution of some shallow-water Foraminifera in the Gulf of Mexico: U. S. Geol. Survey Prof. Paper 254-F, p. $125-140$.

Brady, H. B., 1884, Challenger Rept.: Zoology, v. 9.

Cole, W. S., 1931, The Pliocene and Pleistocene Foraminifera of Florida: Florida Geol. Survey Bull. 6, 79 p.

Cooke, C. W., 1945, Geology of Florida: Florida Geol. Survey Bull. 29, 329 p.

Crouch, R. W., 1952, Significance of temperature on Foraminifera from deep basins off southern California: Am. Assoc. Petroleum Geologists Bull., v. 36, p. 807-843.

Cushman, J. A., 1918, Some Miocene Foraminifera of the coastal plain of the United States: U. S. Geol. Survey Bull. 676. 1921a, Foraminifera from the north coast of Jamaica: U. S. Natl. Mus. Proc., v. 59.

$1921 \mathrm{~b}$, A monograph of the Foraminifera of the north Pacific Ocean: U. S. Natl. Mus. Bull. 71, pt. 6, p. 42, pl. 9, fig. 1.

- 1922a, Shallow-water Foraminifera of the Tortugas region: Carnegie Inst. Washington Pub. 311.

- 1922b, The Foraminifera of the Atlantic Ocean: U. S. Natl. Mus. Bull. 104, pt. 3, p. 83, pl. 16, figs. 1-3.

- 1926, Recent Foraminifera from Puerto Rico: Carnegie Inst. Washington Pub. 344.

Cushman, J. A., and Bronniman, Paul, 1948, Additional new species of arenaceous Foraminifera from shallow waters of Trinidad: Cushman Lab. Foram. Research Contr., v. 24, pt. 2, p. 37-42.

Cushman, J. A., and Cahill, E. D., 1933, Miocene Foraminifera of the coastal plain of the eastern United States: U. S. Geol. Survey Prof. Paper 175-A, p. 32.

Cushman, J. A., and Ozawa, Yoshiaka, 1930, A monograph of the foraminiferal family Polymorphinidae, Recent and fossil: U. S. Natl. Mus. Proc., v. 77, art. 6, 185 p.

Cushman, J. A., and Ponton, G. M., 1932, The Foraminifera of the upper, middle, and part of the lower Miocene of Florida: Florida Geol. Survey Bull. 9, $147 \mathrm{p}$.

D'Orbigny, A. D., 1826, Tableau methodique de la classe des Céphalopodes, Annales sci. nat., v. 7, no. 19, p. 294.

1839, Foraminiferes in Ramon de la Sagra, Histoire physique, politique et naturelle de l'Ile de Cuba, A. Bertrand, Paris, France.

Ellis, B. F., and Messina, A. R., 1940-54, Catalogue of Foraminifera: New York, Am. Mus. Nat. History.

Emiliani, Cesare, 1954, Depth habitats of some species of pelagic Foraminifera as indicated by oxygen isotope ratios: Am. Jour. Sci., v. 252, p. 149-158.

Galloway, J. J., 1933, A manual of Foraminifera: Bloomington, Ind., Principia Press.

Gardner, Julia, 1926, The molluscan fauna of the Alum Bluff group of Florida: U. S. Geol. Survey Prof. Paper 142-C, p. 101-149.

Geyer, R. A., 1950, A bibliography of the Gulf of Mexico: Texas Jour. Sci., v. 2, no. 1.

Hada, Yoshine, 1931, Report of the biological survey of Mutsu Bay; No. 19, Notes on the Recent Foraminifera from Mutsu Bay: Tohoku Imp. Univ., Sci. Repts., ser. 4, v. 6, p. 45-149.

Hedberg, H. D., 1934, Some Recent and fossil brackish to fresh-water Foraminifera: Jour. Paleontology, v. 8, p. 469-476. Israelsky, M. C., 1949, Oscillation chart: Am. Assoc. Petroleum Geologists Bull, v. 33, p. 92-98. 
Kornfeld, M. M., 1931, Recent littoral Foraminifera from Texas and Louisiana: Stanford Univ., Dept. Geology, Contr., v. 1, no. 3.

Lalicker, C. G., and Bermudez, P. J., 1941, Some Foraminifera of the family Textulariidae collected by the first Atlantis Exped.: Torreia, Mus. Poey, Universidad de la Habana, Cuba, no. 8.

Lowman, S. W., 1949, Sedimentary facies in Gulf Coast: Am. Assoc. Petroleum Geologists Bull., v. 33, no. 12, p. 1939-1997.

Myers, E. H., 1943, Life activities of Foraminifera in relation to marine ecology: Am. Philos. Soc. Proc., v. 86, no. 3, p. $439-458$

Natland, M. L., 1933, The temperature and depth distribution of some Recent and fossil Foraminifera in the southern California region: Scripps Inst. Oceanography Bull., Tech. ser. 3 , no. 10, p. 225-230.

Norton, R. D., 1930, Ecologic relations of some Foraminifera: Scripps Inst. Oceanography Bull., Tech. ser., v. 2, p. 331-388.

Parker, F. L., 1948, Foraminifera of the continental shelf from the Gulf of Maine to Maryland: Harvard Coll. Mus. Comp. Zoology Bull., v. 100, no. 2, p. 214-241.

Parker, F. L., Phleger, F. B., and Pierson, J. F., 1953, Ecology of Foraminifera from San Antonio Bay and environs, southwest Texas: Cushman Foundation Foram. Research Special Pub. 2, 75 p.

Phleger, F. B., 1951, Gulf of Mexico Foraminifera, Part 1, Foraminifera, distribution: Geol. Soc. America Mem. 46.
Phleger, F. B., and Parker, F. L., 1951, Gulf of Mexico Foraminifera, Part 2, Foraminifera species: Geol. Soc. America Mem. 46.

Post, R. J., 1951, Foraminifera of the south Texas coast: Inst. Marine Sci. Pub., v. 2, no. 1, p. 165-176.

Rottgardt, Dietrich, 1952, Mikropaleontologisch wichtige Bestandteile recenter brackischer sedimente an der kusten Schleswig-Holsteins: Meyniana, Geol. Inst. Univ. Kiel, Band 1, p. 169-228.

Schroeder, M. C., and Bishop, E. W., 1953, Foraminifera of Late Cenozoic in southern Florida: Am. Assoc. Petroleum Geologists Bull., v. 37, no. 9, 2182-2186.

Strom, K. M., 1936, Land-locked waters; hydrography and bottom deposits in badly ventilated Norwegian fjords with remarks upon sedimentation under anaerobic conditions: Norske Vidensk.-akad. Oslo, 1. Math.-Naturw. Kl., hefte 7, $85 \mathrm{p}$.

Sverdrup, H. U., Johnson, M. W., and Fleming, R. H., 1942, The Oceans: New York, Prentice-Hall, Inc.

Vaughan, T. W., 1918, Some shoal-water bottom samples from Murray Island, Australia, and comparisons of them with samples from Florida and the Bahamas: Carnegie Inst. Washington Pub. 213.

Walton, W. R., 1952, Techniques for recognition of living Foraminifera: Cushman Foundation Foram. Research Contr., v. 3, pt. 2, p. 56-60. 


\section{N D E X}

[Italic numbers indicate descriptions]

Page

Acknowledgments......... 179-180, 192 acutauricularis, Saracenaria advena, Marginulina _..... 186, 195; charts 3-7; pl. 30 Rectobolivina................... 196; charts 3-7 advenum, El phidium _. 183, 184, 185; charts 1-7; pl. 30 aequa, Gaudryina .......... 184, 186, 194; charts 3, 5-7 aequilateralis, Globigerina ...................... 187 Globigerinella...................... 194; chart 7 affinis, Nonion ...... 186, 189, 195; charts 3, 5-7; pl. 30 Triloculina agglutinans, Ouinqueloculina $\ldots . . . . .196$; charts 4,6,7 agglutinata, Quinqueloculina ............... 185 akneriana, Quinqueloculina .................... 182, $183,185,196$; charts $1,2,6,7 ;$ pl. 29

Alaska, MV Algal belt, location. ....... . . . Alum Bluff group, dominant species . . . 190 (table) americanus, Robulus..................... 190 spinosus, Robulus...................... 190

Ammoastuta Ammobaculites. . ................ 182, 184, 187, 191 exiguus ................................. 183,

$183,185,184,192$; charts $1,2,7 ; \mathrm{pl} .30$ exilis ................... 192; chart 7; pl. 30 salsus ....... . . . 182, 183, 192; charts 1, 2; pl. 30 Amphistegina .................. 181, 182, 189, 190, 191

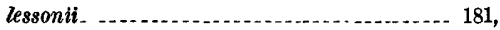
$184,185,186,188,189,192 ;$ charts $3,5-7$ ampla, Saracenaria ............... 197; charts 5, 6 angulatus, Archaias _...... 184, 185, 186, 192; charts 4-7 Angulogerina bella . . . . . . . . . 192; charts 3-7 Anomalina . . . . . . io . ... . . . . . . . . 186, 192; charts 4-7; pl. 31 Anomalinoides. antillarum, Eponides Spiroloculina ...................... 197; pl. 29

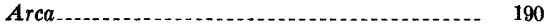
zone. . . Archaias angulatus _............ 184, 185, 186, 192; charts 4-7 sp

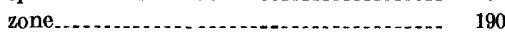

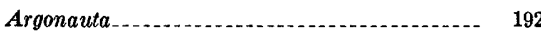

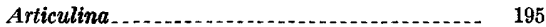

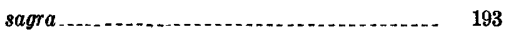
Astacolus ovatus . . . . Asterigerina ................................... 185, 189 carinata $\ldots \ldots \ldots . . .184,185,186,191,193 ;$ charts 3-7 chipolensis. . . . floridana miocenica

atlantica, Nodobaculariella .............. 195; charts 3-7 Nonionella Pavonina....................... 195; charts 5-7 Proteonina .................... 196; charts 3, 4,7 Reussella....................... 197; charts 1, 3-7 auberiana laevis, Uvigerina................. 199 auriculata, Wiesnerella australis, Guttulina ................... 194; charts 3-7 barleeanus, Nonion barrettii, Textularia....................... 186 Textulariella basilica, Rotorbinella _ 186, 197, 199; charts 5-7; pl. 31 bassleri, Rotorbinella. . ..................... 199 Bathysiphon sp.................... 187, 193; chart 2 bella, Angulogerina ................. 192; charts 3-7 bellatula, Triloculina bellula, Uvigerina.... 184, 186, 198, 199; chart 7; pl. 31 bertheloti, Han zawaia . ..... 186, 195; charts 6,7; pl. 31 bicostata, Quinqueloculina.... 183, 196; charts 1-3,5-7 Bigenerina floridana ........................ 190 irregularis . .............. 184, 186, 193; charts 3-7

Bolivina......... 195 daggarius . . . 184, 186, 193; charts $3,5,7 ;$ pl. 31 fragilis . . . ........................... 193; chart 6 goësii ............ 184, 186, 188, 191, 193; charts 5-7 pulchella primitiva . .................. 193; chart 7 striatula. . . . subaenariensis mexicana ... 193; charts 3,5 ; pl. 31 bosciana, Quinqueloculina . 183, 196; charts 1-7; pl. 29 Bottom plants, effect on faunal distribution. 189,192 Brackish habitat, dominant species..... 190 (table) bradyana, Siphonina Page . Buccella hannai Bulimina marginata 193; charts $1,2,4-7$

Buliminella elegantissima........ 190, 193; charts 1,2

bulloides, Globigerina............ 187, 194; charts 3-6 Sphaeroidina $\ldots . . . . . . . . . . . . . . .187,197$; chart 7 calcar, Robulus........ 184, 186, 197; charts 3-6; pl. 30 caloosahatcheensis, Triloculina linneiana

Cancellaria. . . . . . zone. 190
190 Cancris sagra.................. 193; charts 4-7 candeiana, Textularia _... 184, 185, 186, 197; charts 4-7 Candeiana nitida. . . ................ 187, 193; chart 7 Cardium taphrium .......................... 190 zone carinata, Asterigerina_.184, 185, 186, 191, 193; charts 3-7 Cassidulina laevigata......... 193 Lingulina . . . . . . . . .

Cassidulina curvata _........ 184, 193; charts 3, 5-7 laevigata ....................... 193; charts 3, 5-7

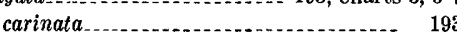

cassis, Nodotaculariella Charlotte Harbor, Fla .............. 179, 181, 183, 184 Chipola formation, dominant species..... 190(table) environment of deposition ............. 190,191

chipolensis, Asterigerina..................... 190

Cilicides................................ 192 de primus................... 193; charts 6,7 pseudoungerianus....................... 184 $186,188,191,193$; charts $3-7$; pl. 31 rol ertsonianus _............ 186, 193; chart 7 Cibicidina Cocohatchee River, Fla................... 181 comata, Pyrgo.................... 196; charts 3, 4, 6 comatula, Glandulina........... 194; charts 3, 7 comis, Triloculina linneiana $\ldots$.- 198; charts 6, 7; pl. 29 communis, Dentalina __ 190, 193; charts 5, 7 compressa, Virgulina.......................... 198 compta, Quinqueloculina concentrica, Hanzawaia ...................... 184 $185,186,188,191,195 ;$ charts $3-7$ Stomatorbina ...................... 197; chart 5 concinnus, Discorbis $185,186,193$; charts $1,3-7$; pl. 31 conglobata, Globigerinoides.......... 187, 194; chart 7 conica, Textularia..... 184, 186, 197; charts 3-7; pl. 30 constans, Pseudoclavulina ..................... 186 196,198 ; charts 5,7 ; pl. 30 convergens, Robulus................................. cribrorepandus, Poroeponides........ 196; charts 4-7 curvata, Cassidulina........... 184, 193; charts 3, 5-7 Cyclammina............. 187 daggarius, Bolivina _.. 184, 186, 193; charts $3,5,7$; pl. 31 densicostata, Marginulinopsis....... 186, 195; chart 7 Dentalina communis ............ 190, 193; charts 5, 7 depressa, Spiroloculina .......... 197; charts 3, 4, 6, 7 deprimus, Cibicides . . . . . . . . ... 193; charts 6, 7 Dimorphina sp . . . discoidale, Elphidium . ............. 193; charts 2-7 Discorbis....................................... 185 concinnus.. 184, 185, 186, 193; charts 1, 3-7; pl. 31 floridanus. ..... 184, 185, 186, 190, 193; charts 1-7 fioridensis . ............ 186, 193; charts 4-7; pl. 31 Duplin marl, dominant species........... 190 (table) environment of deposition .............- 190 dutemplei, Quinqueloculina $196 ;$ charts $4,5,7 ;$ pl. 29

Ecphora 190 zone $\ldots \ldots \ldots$........... 190 eggeri, Globigerina. Ehrenbergina spinea elegans, Höglundina............. 186, 195; charts 5, 6 elegantissima, Buliminella....... 190, 193; charts 1, 2 Elphidium .......................... 182, 184,187, 19 advenum ......... 183, 184, 185; charts 1-7; pl. 30 discoidale ...................... 193; charts 2-7 gunteri _ _ 182, 183, 184, 185, 194; charts 1-6; pl. 30 galvestonense...................... 194 mexicanum ............. 185, 194; chart 7; pl. 30 poeyanum. ......... 183, 184, 185, 194; charts 1-7 rugulosum ....... 183, 184, 194; charts 1, 2; pl. 30
Eponides antillarum ................ 194; charts 3-7 repandus 196 exiguus, $A$ mmobaculites . ................... 183 184, 192; charts 1, 2, 7; pl. 30 exilis, Ammobaculites exorna, Planulina ......................... 196 flintii, Uvigerina............... 184, 186, 198; charts 5-7 floridana, Asterigerina....................... 190 Bigenerina Spiroplectammina _..._. 186, 197; charts 4-7 Valvulineria.............................. 190 floridanus, Discorbis....................... 184 $185,186,190,193$ : charts $1-7$ floridensis, Discort is...... 186, 193; charts 4-7; pl. 31 foliacea occidentalis, Textularia

190, 197; charts 3-7; pl. 30

Fort Myers, Fla foveolata, Planulina......... 184, 186, 195; charts 5-7 fragilis, Bolivina..................... 193; chart 6 Frondicularia sagittula ................. 194; chart 5 fusca, Miliammina................... 198 galvestonense, Elphidium gunteri.............-. 194 Gaudryina aequa ........ 184, 186, 194; charts 3, 5-7 stavensis................. 186, 194; chart 5; pl. 30 glabra, Marginulina Glandulina................................. 194 comatula laevigata............................... 194 Glo'igerina aequilateralis. bulloides 187,194 ; charts $3-7$ eggeri $\ldots \ldots \ldots$.................. 187, 194; charts 3-7 Globigerinella aequilateralis _............ 194; chart 7 Globigerinoudes conglobata............. 187, 194; chart 7 rulra 186, 187, 188, 192, 194; charts 3-7 sacculifera Globorotalia menardii......... 187, 190, 194; charts 3-7 puncticulata.............. 187, 194; chart 7; pl. 31 truncatulinoides............ 187, 194; charts 3, 5-7 tumida . ......... 187, 188, 191, 194; charts 3-7 Glycymeris waltonensis ................. 190 zone 190 goëssi, Bolivina ..... 184, 186, 188, 191, 193, charts 5-7 grateloupi, Nonionella gunteri, Elphidium $183,184,185,194$; charts 1-6; pl. 30 galvestonense, Elphidium.............. 194 Guttulina australis .................. 194; charts 3-7 regina................... 194 Gypsina vesicularis................ 194; charts 4-7 hannai, Buccella . . ............ 193; charts 1, 2, 4-7 hantkeni, Marginulina.................. 195; chart 5 Han zawaia concentrica_ 184, 185, 186, 188, 191, 195; charts 3-7 strattoni........ 184, 185, 188, 191, 195; charts 3-7

Haplophragmoides

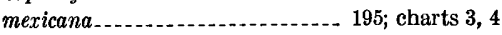
Hawthorn formation, environment of deposi-

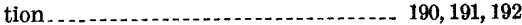
hispido-costata, Uvigerina ................... 184, 186, 198; charts 3, 5-7; pl. 31 Höglundina elegans............. 186, 195; charts 5, 6 horrida, Quinqueloculina ...... 185, 196; charts 3, 4, 6 io, Anomalina ........... 186, 192; charts 4-7; pl. 31 irregularis, Bigenerina....... 184, 185, 193; chart 3-7 jugosa, Quinqueloculina. ................ 182, $183,185,196$; charts $1-6$; pl. 29 Karreriella bradyi. . . ............ 186, 195; charts 5, 7 Laboratory procedure . laevigata, Cassidulina.............. 193; charts 3, 5-7 Glandulina............................. 194 Trochammina_............. 198; chart 1; pl. 29 laevigata carinata, Cassidulina................. 193 laevis, Uvigerina _......................... 199 Uvigerina auberiana_................... 199 Lagena spp.............................. 195; chart 5 Lagenonodosaria scalaris ...... 195; charts 5,$7 ; \mathrm{pl} .30$ lamarckiana, Ouinqueloculina ........... 183, lamellata, Siphogenerina lessonii, Amphistegina........................ 181, $184,185,186,188,189,192$; charts $3,5-7$ Lingulina carinata...................... 195; chart 7 
Page caloosahatcheensis, Triloculina comis, Triloculina ......... 198: charts 6, 7; pl. 29 Little Manatee River, Fla ................... 183

Loxostomum -........................... 195 mayori.................. 195; charts 1, 7; pl. 31 subspinescens _............ 195; charts 6, 7; pl, 31 marginata, Bulimina .................... 193; chart 3

Marginulina ............................. 195 advena $\ldots . . . . . . . . . . .186,195$; charts 3-7; pl. 30 glabra hantkeni $i_{\text {............................... 195; chart } 5}$ subbullata $\ldots \ldots \ldots \ldots$

Mfarginulinopsis densicostata $\ldots . . . . . .186,195 ;$ chart 7 subaculeata ........... 186, 195; charts 3, 5-7 pl. 30 mayori, Loxostomum ........ 195; charts 1, 7; pl. 31 Textularia ............. 184, 186, 197; charts 3-7 mediterranensis, Planor_bulina _.... 195; charts 1, 3-7 menardii, Globorotalia ....... 187, 190, 194; charts 3-7 mexicana, Bolivina subaenariensis _............ 193;

charts 3,5 ; pl. 31

Haplophragmoides ................. 195; charts 3,4 Nodobaculariella Pseudoclavulina ........................ 198 mexicanum, Elphidium m........ 185, 194; chart 7; pl. 30 Miliammina fusca .......................... 198 miocenica, Asterigerina a..................... 190 Mobile, Ala_..._. 179, 181, 185, 186 nasuta, Pyrgo _.................. 196; charts 3, 5, 7 Nautilus_.................................. 192 nitida, Candeiana Nodobaculariella ........................... 195 atlantica ................... 195; charts 3-7

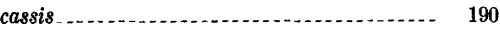
mexicana ......... 195; charts 5,7 ; pl. 29

Nonion affinis _... 186, 189, 195; charts 3, 5-7 pl. 30 barleeanus............................ 189, 195 Nonionella atlantica................. 195; charts 2-7 grateloup $i$...... 195 ; charts 4-7 Nutrients, effect on faunal distribution - 189, 191, 192 Oak Grove sand member. See Alum Bluff group.

obliquiloculata, Pulleniatina _...... 187, 196, charts 3-7 occidentalis, Schenckiella .................. 197 Textularia foliacea. 186, 190, 197; charts 3-7; pl. 30 Offshore zones, dominant species ........ 190 (table) olianaensis, Siphotextularia...... 197; chart 5; pl. 30 orbitolitoides, Sorites _................... 197; charts 1-7 Orbulino universa .......... 187, 190, 195; charts 3-7 ornata, Planulina $185,186,188,189,191,196$; charts $3-7$ ovatus, Astacolus _.................. 193; charts 5-7 Oxygen, effect on faunal distribution ......... 189 pacifica simplex, Trochammina ................ 198 Panama City, Fla _............... 181, 185 parkeri, Uvigerina Pavonina atlantica $\quad$ 195; charts 5-7 Peneroplis proteus .............. 185, 195; charts 4-7 peregrina, Uvigerina _................... 190 peruviana, Pyrgo .............. 196; charts 1, 4,6,7 $\mathrm{pH}$, effect on fauna distribution ........ 188-189, 191 Pine Island Sound, Fla ............ 179, 181, 183, 184 Planorbulina mediterranensis ...... 195; charts 1,3-7 Planulina exorna foreolata $\ldots . . . . .184,186,195$; charts 5-7 ornata ... 184, 185, 186, 188, 189, 191, 196; charts 3-7 poeyana, Quinqueloculina _. 183, 196; charts 1-3, 5-7; pl. 29 poeyanum, Elphidium _.. 183, 184, 185, 194; charts 1-7 polygona, Quinqueloculina.............. 196; chart 6 Polymorphina pulchella .............. 196; charts 3-7 Pompino, MV ............................ 179 Poroeponides cribrorepandus. ........ 196; charts 4-7 primitita, Bolivina pulchella.......... .193 ; chart 7 Proteonina atlantica .............. 196; charts 3,4, 7 proteus, Peneroplis .............. 185, 195; charts 4-6 Pseudoclavulina constans ............. 186, 196, 198; charts 5,$7 ;$ pl. 30

mexicana _........................... 198 Pseudoglandulina pseudotrochus, Textularia _... 186, 197; chart 5; pl. 30 pseudoungerianus, Cibicides.......... 184, 186, 188, 193; charts 3-7; pl. 31

pulchella, Polymorphina .............. 196; charts 3-7 primitiva, Bolivina ................ 193; chart 7 Pullenia quinqueloba .................... 196; chart 7 Pulleniatina obliquiloculata ...... 187, 196; charts 3-7 puncticulata, Globorotalia.... 187, 194; chart 7; pl. 31 Pyrgo comata ................... 196; charts 3, 4,6 nasuta .................... 196; charts 3,5,7 peruviana $\ldots \ldots \ldots \ldots . . . . .196$; charts 1, 4,6,7 quinqueloba, Pullenia ................. 196; chart 7 Quinqueloculina $\ldots$ *agglutinans ................. 196; charts 4,6,7

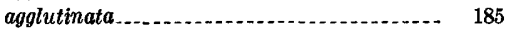
akneriana $182,183,185,196$; charts 1, 2, 6, 7; pl. 29 bicostata $\ldots . . . . . . . . . . . .183,196$; charts 1-3, 5-7 bosciana $\ldots . . . . . . . . . .183,196$; charts 1-7; pl. 29 compta ............... 196; charts 3-7; pl. 29 dutemplei_......... 185, 196; charts 4, 5, 7; pl. 29 horrida $a_{\ldots} \ldots \ldots \ldots$. jugosa ........ 182, 183, 185, 196; charts 1-6; pl. 29 lamarckiana ........... 183, 185, 196; charts 1-7 poeyana .......... 183, 196; charts 1-3, 5-7; pl. 29 polygona _ _ 196; chart 6 rhodiensis.................. 196; chart 5; pl. 29 Raphanulina tuberculata................... 196 Rectobolivina advena regina, Guttulina ........................... 194 Reophax scorpiurus ..................... 197; chart 3 repandus, Eponides _........................... 196

Reussella atlantica rhodiensis, Quinqueloculina ...... 196; chart 5; pl. 29 robertsonianus, Cibicides_.......... 186, 193; chart 7

Robulus americanus americanus spinosus. ................... 190 calcar_........... 184, 186, 197; charts 3-7 pl. 30 convergens. ......................... chart 6 stephensoni......... 197; charts 4, 5; pl. 30 suborbicularis.......... 197; charts 4-6; pt. 30 Rotorbinella basilica .- 186, 197, 1s9; charts 5-7; pl. 31 bassleri_......................... 199 transluscens__._.................... 199 versiformis ........................... 199 rubra, Globigerinoides_...................... 186, $187,188,191,194$; charts $3-6$ rugulosum: Elphidium _................ 183 , sacculifera, Globigerinoides.. 187, 194; charts 5-7 sagittula, Frondicularia _. 194; chart 5 sagra, Articulina a........................ 193 Cancris ................................ 193; charts 4-7 St. Petersburg, Fla ...................... 181, 182 Salinity, effert on faunal distribution. ...... 189, 191 salsus. Ammobaculites..................... 182, 183,192 ; charts 1,2 ; pl. 30 San Carlos Bay, Fla San Diego, Calif .......................... 189 Saracenaria acutauricularis_................. 190 ampla scalaris, Lagenonodosaria . 195; charts 5,7 ; pl. 30 Schenckiella occidentalis ..................... 197 schreibersiana, Virgulina.......... 198; charts 3-7 scorpiurus, Rheophax............... 197; chart 3 secasensis, Textularia $\ldots . . . . . . . . .185,187$; chart 1, 2, 4-7; pl. 30 Shoal River formation, Oak grove sand mem-

ber, dominant species Sigmoilina subpoeyana _..._._.197; charts $3,5,6,7$; pl. 29 tenuis _................... 197; charts 5, 7 simplex, Trochammina pacifica simplissima, Trochammina_... 198; chart 4; pl. 29 Siphogenerina lamellata ................... 190 Siphonina bradyana .............. 197; charts 3-7 Siphotextularia olianaensis_... 197; chart 5; pl. 30 sobrinus, Streblus _._182, 183, 184, 185, 197; charts 1-3, 5 Sorites orbitolitoides ............... 197; charts 1-7 sp Sphaeroidina bulloides_......... 187, 197; chart 7 spinea, Ehrenbergina......... 186, 193; chart 5, 7

*Error for Q. aglutinans.
Page

spinosus, Robulus americanus................. 190 Spiroloculina antillarum................ 197; pl. 29 depressa. _. . 197; charts 3, 5-7 Spiroplectammina fioridana _.... 186, 197; charts 4-7 stavensis, Gaudryina ......... 186, 194; chart 5; pl. 30 stephensoni, Robulus_.......... 197; charts 4, 5; pl. 30 Stomatorbina concentrica strattoni, Han zawaia.. 184,185, 188, 191, 195; charts 3-7 Streblus .. ......... 182, 184, 185, 187, 188, 189, 190, 191 sobrinus _...... 182, 183, 184, 185, 197; charts 1-3, 5 tepidus -... 182 , $183,184,185,188,189,197$; charts 1-7; p. 31 striatula. Bolivina ....................... 193; chart 2 subaculeata, Marginulinopsis.................. 186, 195 ; charts 3, 5-7; pl. 30 subaenariensis mexicana, Bolivina............ 193; charts 3, 5; pl. 31

subbullata, Marginulina suborbicularis, Robulus_....... 197; charts 4-6; pl. 30 subpoeyana, Sigmoilina..... 197; charts 3, 5-7; pl. 29 subspinescens, Loxostomum _._ 195; charts 6, 7; pl. 31 Tampa Bay, Fla ................... 179, 181, 182, 183 Tampa limestone, dominant species..... 190 (table) environment of deposition .............. 189-190 taphrium, Cardium ....................... 190 Tarpon Springs, Fla_....................... 181, 182 Temperature, effect on faunal distribution _... 188 tenuis, Sigmoilina. ................... 197; charts 5 ,7 tepidus, Streblus $183,184,185,188,189,197$; charts 1-7; pl. 31

Textularia barrettii ${ }^{*}$.......................... 186 candeiana conica $\ldots . . . . . . . . . .184,186,197$; charts $3-7$; pl. 30 foliacea occidentalis _ 186, 190, 197; charts 3-7; pl. 30 mayori.............. 184, 185, 186, 197, charts 3-7 pseudotrochus........... 186, 197; chart 5; pl. 30 secasensis. 182, 183, 185, 197; charts 1, 2, 4-7; pl. 30 Textulariella barrettii .................. 197; charts 5, 7 tortuosa, Triloculina transluscens, Rotorbinella ................... 199 trigonula, Triloculina .... 182, 183, 190, 198; charts 1-7 Triloculina affinis...................... 197; chart 5 bellatula $\ldots \ldots \ldots \ldots \ldots$................. 198; chart 1 linneiana linneiana caloosahatcheensis.............. 198 comis ................ 198; charts 6, 7; pl. 29 tortuosa trigonula .............. 182, 183, 190, 198; charts 1-7

Trochammina_......................... 187 laevigata. ................... 198; chart 1; pl. 29 pacifica simplex -.............. 198 simplissima .............. 198; chart 4; pl. 29 truncatulinoides, Globorotalia . ... 187; 194: charts 3-7 tuberculata, Raphanulina tumida, Globorotalia _..... 187, 188, 191, 194; charts 3-7 Turbidity, effect on faunal distribution... 189, 191-192 universa, Ordulina ............ 187, 190, 195; charts 3-7

Uvigerina auberiana laevis bellula $\ldots . . . . . . . .184,186,198,199$; chart 7; pl. 31 fintii ................ 184, 186, 198; charts 5-7 hispido-costata _.. 184, 186, 198; charts 3, 5-7; pl. 31 laevis -

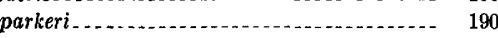
peregrina sp ........................... 188, 190, 19

Vaginulina

Valvulineria $\ldots . . . . . . . . . . . . . . . . .190,198$; chart 7 floridana............................. 190

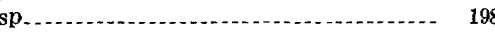
versiformis, Rotorbinella vesicularis, Gypsina

Virgulina compressa _................... 198 schreibersiana ................... 198; charts 3-7 waltonensis, Glycymeris...................... 190 Wiesnerella auriculata

Yoldia

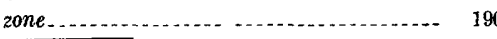

*Error for Textularia barrettii. 
Plates 29-31 


\section{PLATE 29}

Figure 1. Sigmoilina subpoeyana (Cushman) (p. 197). Hypotype, USNM 624378.

2. Spiroloculina depressa D'Orbigny (p. 197). Hypotype, USNM 624384.

3. Quinqueloculina akneriana D'Orbigny (p. 196). Hypotype, USNM 624356.

4. Quinqueloculina bosciana D'Orbigny (p. 196). Hypotype, USNM 624359.

5. Quinqueloculina compta Cushman (p. 196). Hypotype, USNM 624360.

6. Quinqueloculina poeyana D'Orbigny (p. 196). Hypotype ,USNM 624365.

7. Nodobaculariella mexicana (Cushman) (p. 195). Hypotype, USNM 624336.

8. Quinqueloculina jugosa Cushman (p. 196). Hypotype, USNM 624363.

9. Quinqueloculina dutemplei D'Orbigny (p. 196). Hypotype, USNM 624361.

10. Quinqueloculina rhodiensis Parker (p. 196). Hypotype, USN M 624367.

11. Triloculina bellatula Bandy, n. sp. (p. 198). Holotype, USNM 624397.

12. Triloculina linneiana D'Orbigny var. comis Bandy, n. var. (p. 198, 199). Holotype, USNM 624398.

13. Trochammina laevigata Cushman and Bronniman (p. 198). Hypotype; $a$, ventral view; $b$, edge view; $c$, dorsal view; USNM 624400.

14. Trochammina simplissima Cushman and McCulloch (p. 198). Hypotype; $a$, dorsal view; $b$, edge view; $c$, ventral view; USNM 624401. 

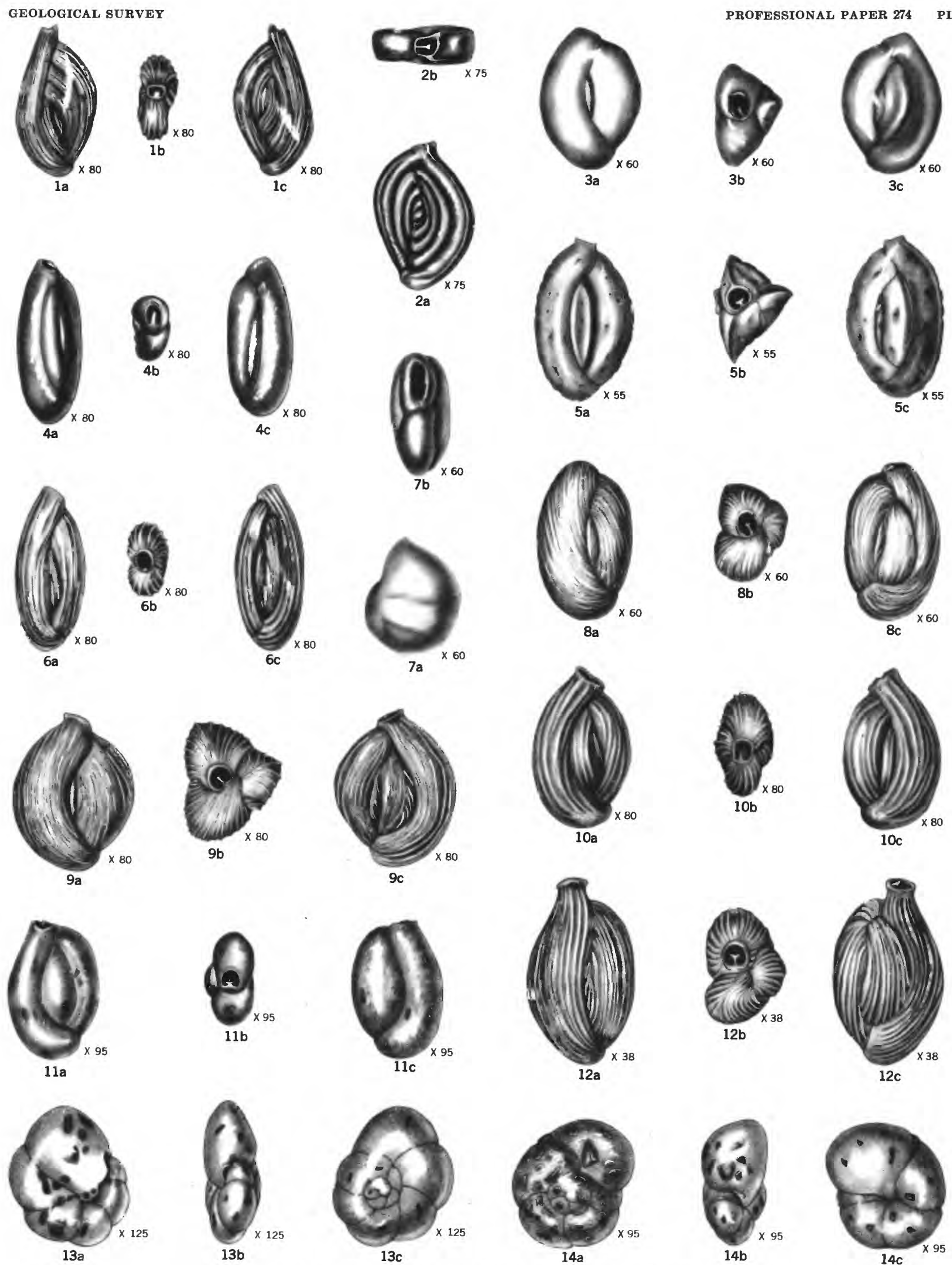

$$
\text { FORAMINIFERA OF NORTHEASTERN GULF OF MEXICO }
$$




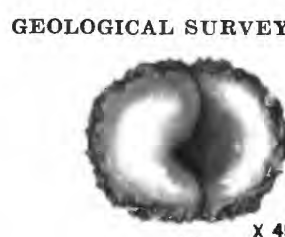

1b

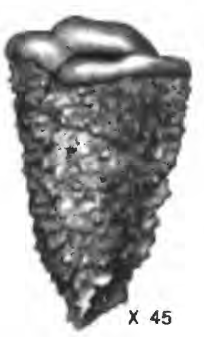

$1 \mathrm{a}$
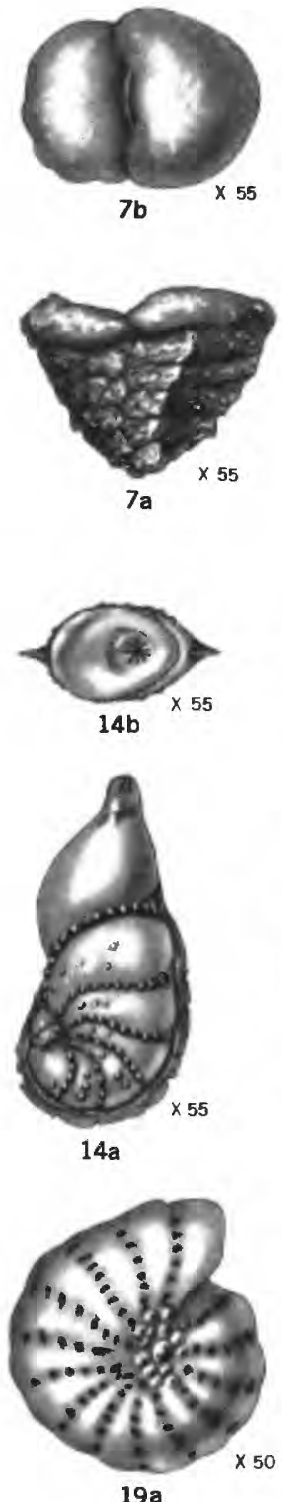
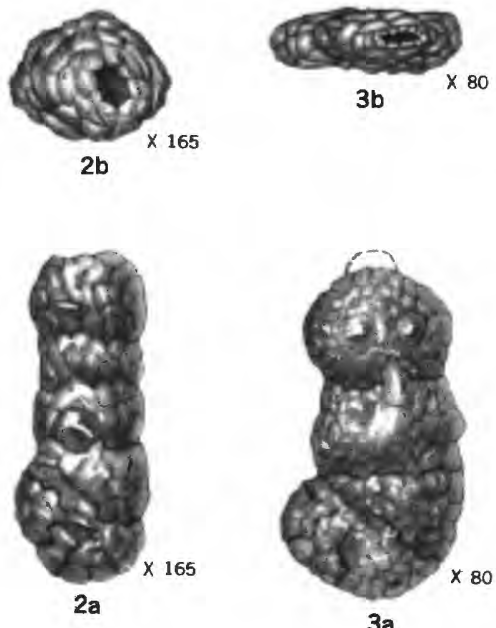

3a

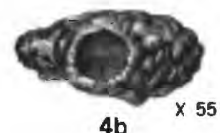

$4 b$
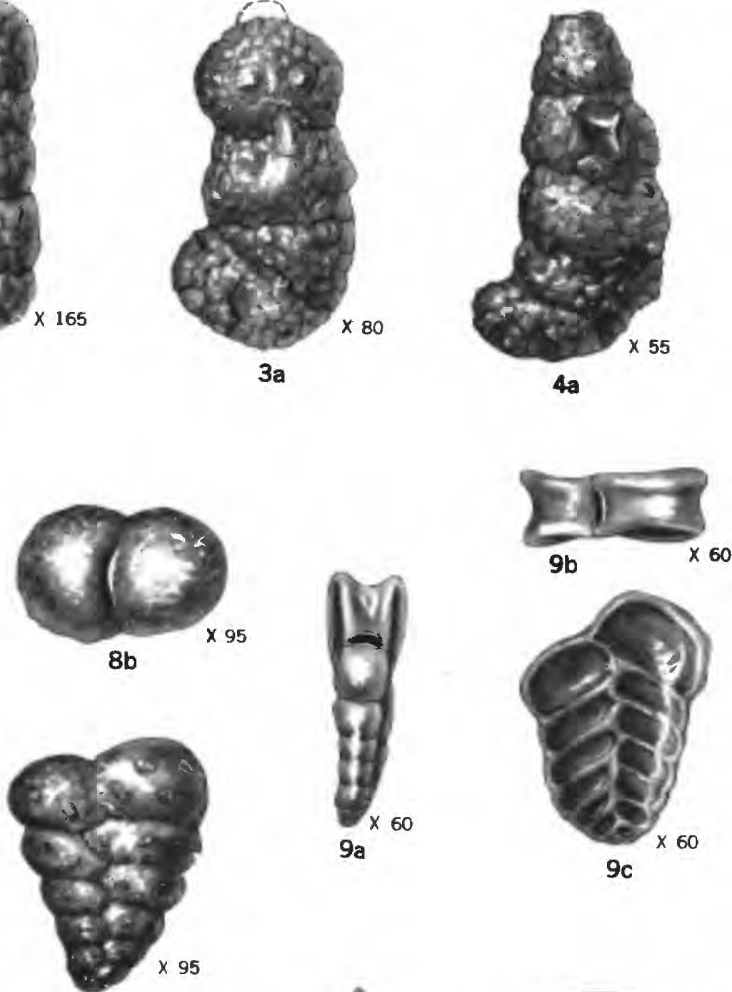

8 a
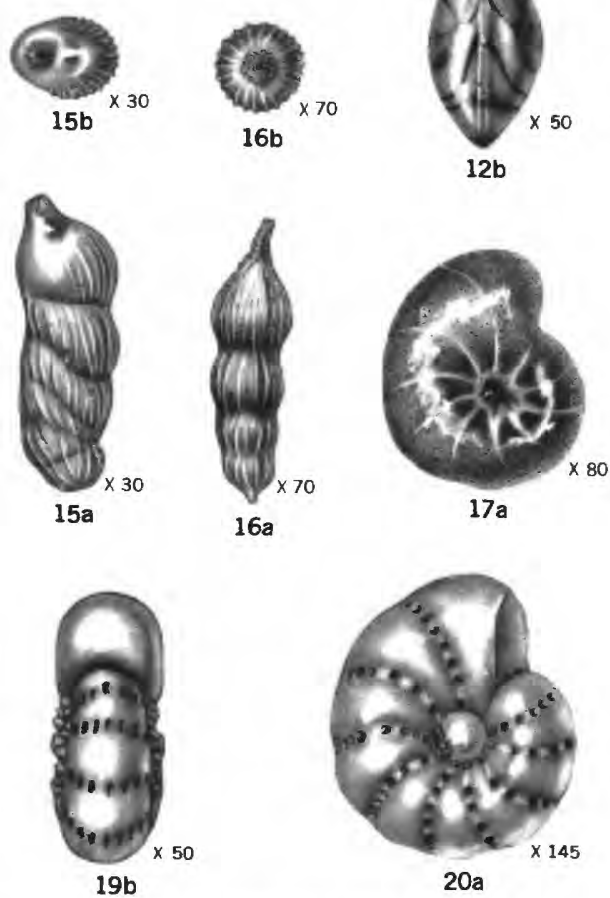

FORAMINIFERA OF NORTHEASTERN GULF OF MEXICO
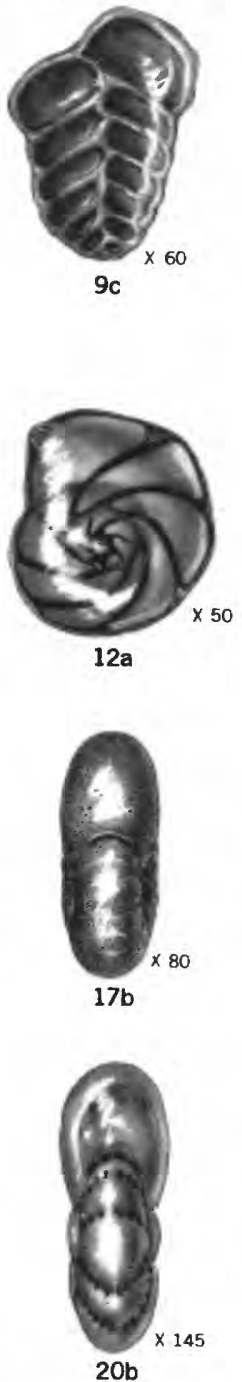
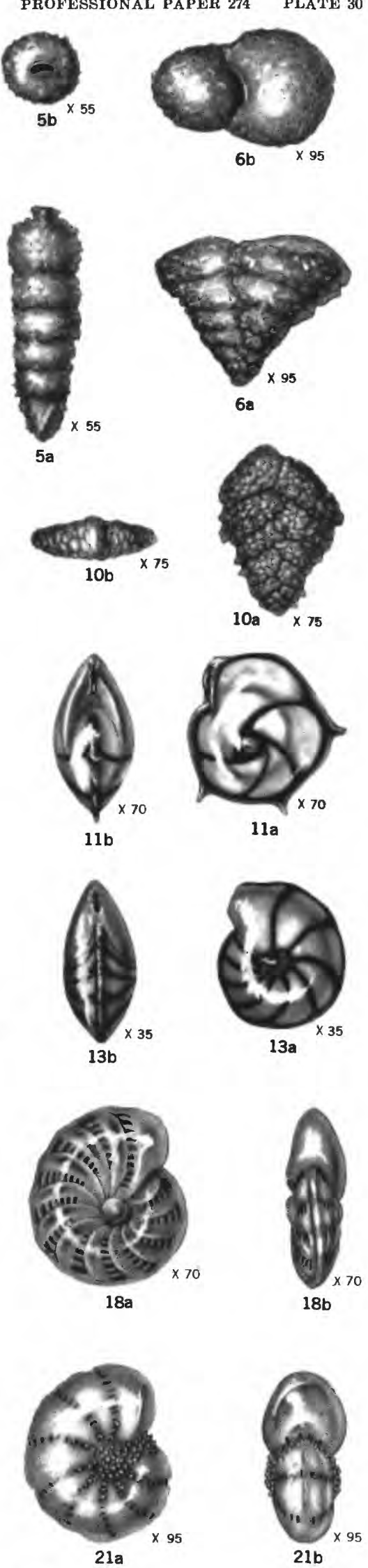


\section{PLATE 30}

FIGURE 1. Gaudryina stavensis Bandy (p. 194). Hypotype, USNM 624307.

2. Ammobaculites exiguus Cushman and Bronniman (p. 192), Hypotype, USNM 624264.

3. Ammobaculites exilis Cushman and Bronniman (p. 192). Hypotype, USNM 624265.

4. Ammobaculites salsus Cushman and Bronniman (p. 192). Hypotype, USNM 624266.

5. Pseudoclavulina constans Bandy, n. sp. (p. 198). Holotype, USNM 624349.

6. Textularia conica D'Orbigny (p. 197). Hypotype, USNM 624390.

7. Textularia pseudotrochus Cushman (p. 197). Hypotype, USNM 624393.

8. Textularia secasensis Cushman and McCulloch (p. 197). Hypotype, USNM 624394.

9. Siphotextularia olianaensis Colom and Ruiz de Gaona (p. 197). Hypotype, USNM 624381.

10. Textularia foliacea Heron-Allen and Earland var. occidentalis Cushman (p. 197). Hypotype, USNM 624391.

11. Robulus calcar (Linne) (p. 197). Hypotype, USNM 624372.

12. Robulus suborbicularis Parr (p. 197). Hypotype, USNM 624374.

13. Robulus cf. stephensoni Cushman (p. 197). Hypotype, USNM 624373.

14. Marginulinopsis subaculeata (Cushman) (p. 195). Hypotype, USNM 624334.

15. Marginulina advena (Cushman) (p. 195). Hypotype, USNM 624331.

16. Lagenonodosaria scalaris (Batsch) (p. 195). Hypotype, USNM 624327.

17. Nonion affinis (Reuss) (p. 195). Hypotype, USNM 624337.

18. Elphidium advenum (Cushman) (p. 193). Hypotype, USNM 624297.

19. Elphidium gunteri Cole (p. 194). Hypotype, USNM 624300.

20. Elphidium mexicanum Kornfeld (p. 194). Hypotype, USNM 624301.

21. Elphidium rugulosum Cushman and Wickenden (p. 194). Hypotype, USNM 624303. 


\section{PLATE 31}

Figure 1. Globorotalia puncticulata (D'Orbigny) (p. 194). Hypotype; $a$, ventral view; $b$, edge view; $c$, dorsal view; USNM 624316.

2. 'Streblus tepidus (Cushman) (p. 197). Hypotype; $a$, ventral view; $b$, edge view; $c$, dorsal view; USNM 624388.

3. Rotorbinella basilica Bandy, n. sp. (p. 197, 199). Holotype; $a$, ventral view; $b$, edge view; $c$, dorsal view; USNM 624375.

4. Discorbis concinnus (H. B. Brady) (p. 193). Hypotype; $a$, ventral view; $b$, oblique view; $c$, dorsal view; USNM 624293.

5. Discorbis floridensis Cushman (p. 193). Hypotype; $a$, dorsal view; $b$, oblique view; $c$, ventral view; USNM 624295.

6. Hanzawaia bertheloti (D'Orbigny) (p. 195). Hypotype; $a$, ventral view; $b$, edge view; $c$, dorsal view; USNM 624321.

7. Anomalina io (Cushman) (p. 192), Hyptoype; $a$, dorsal view; $b$, edge view; $c$, ventral view; USNM 624269.

8. Cibicides pseudoungerianus (Cushman) (p. 193). Hypotype; $a$, ventral view; $b$, edge view; $c$, dorsal view; USNM 624289.

9. Bolivina daggarius Parker (p. 193). Hypotype, USNM 624278.

10. Bolivina subaenariensis Cushman var. mexicana Cushman (p. 193). Hypotype, USNM 624281.

11. Loxostomum mayori (Cushman) (p. 195). Hypotype, USNM 624329.

12. Loxostomum subspinescens (Cushman) (p. 195). Hypotype, USNM 624330.

13. Uvigerina bellula Bandy, new name (p. 198, 199). Holotype, USNM 624402.

14. Uvigerina hispido costata Cushman and Todd (p. 198). Hypotype, USNM 624404. 

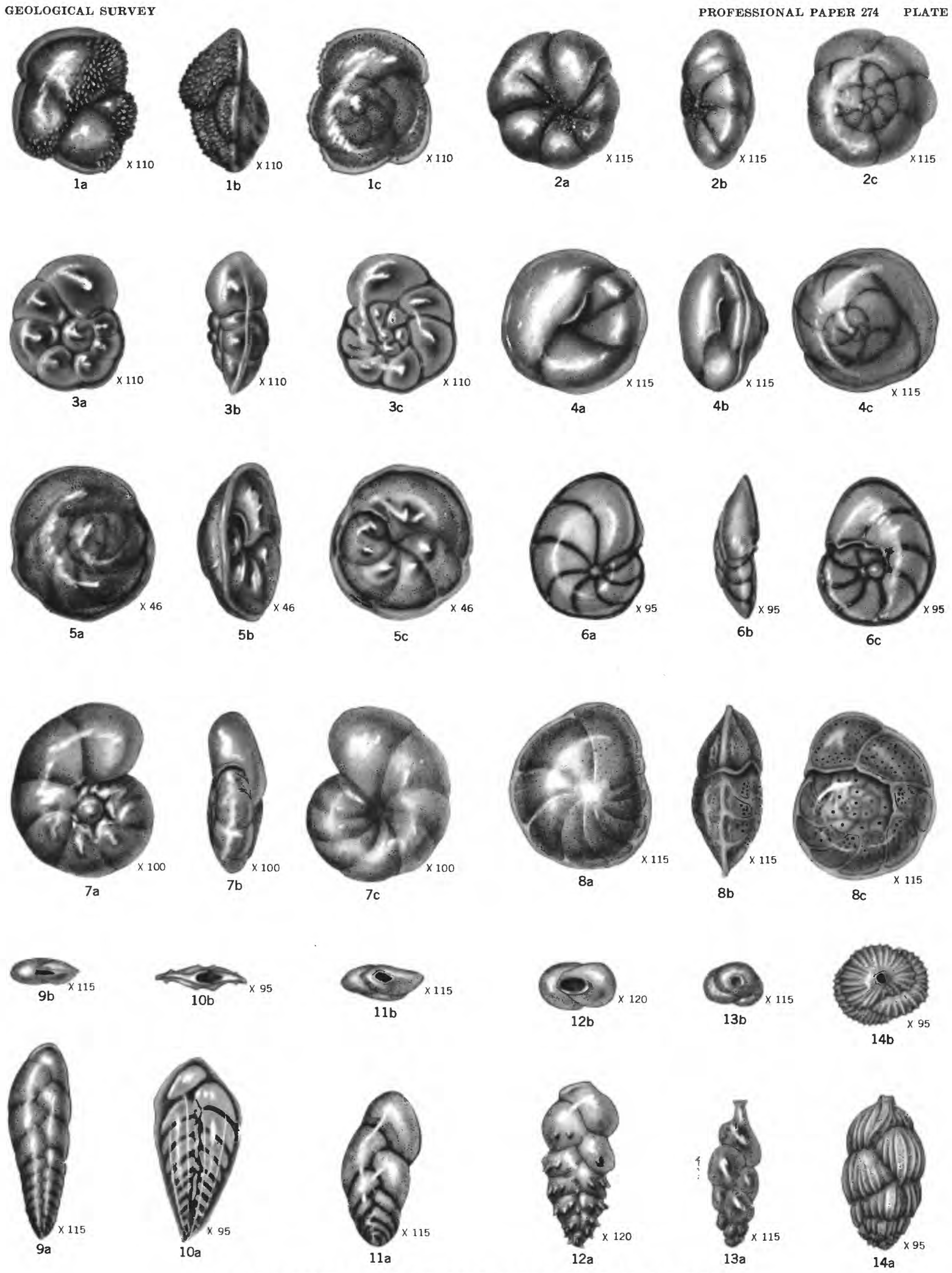

FORAMINIFERA OF NORTHEASTERN GULF OF MEXICO 